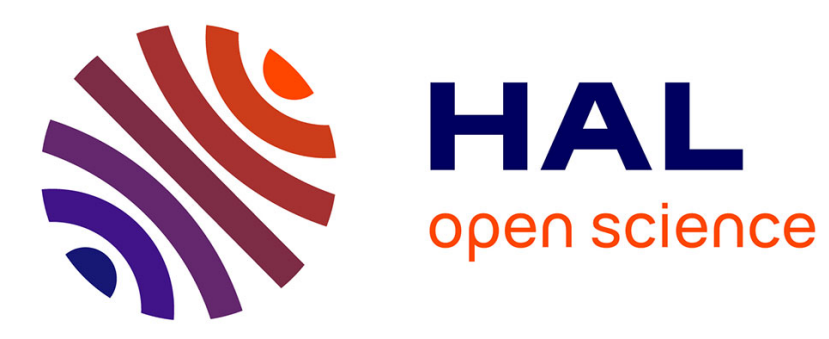

\title{
Tracking selenium in the Chalk aquifer of northern France: Sr isotope constraints
}

Lise Cary, Hind Benabderraziq, Jamal Elkhattabi, Laurence Gourcy, Marc Parmentier, Julie Picot, M. Khaska, Alexandra Laurent, Philippe Négrel

\section{- To cite this version:}

Lise Cary, Hind Benabderraziq, Jamal Elkhattabi, Laurence Gourcy, Marc Parmentier, et al.. Tracking selenium in the Chalk aquifer of northern France: Sr isotope constraints. Applied Geochemistry, 2014, 48, pp.70-82. 10.1016/j.apgeochem.2014.07.014 . hal-01053410

\section{HAL Id: hal-01053410 https: / hal-brgm.archives-ouvertes.fr/hal-01053410}

Submitted on 30 Jul 2014

HAL is a multi-disciplinary open access archive for the deposit and dissemination of scientific research documents, whether they are published or not. The documents may come from teaching and research institutions in France or abroad, or from public or private research centers.
L'archive ouverte pluridisciplinaire HAL, est destinée au dépôt et à la diffusion de documents scientifiques de niveau recherche, publiés ou non, émanant des établissements d'enseignement et de recherche français ou étrangers, des laboratoires publics ou privés. 


\section{Tracking selenium in the Chalk aquifer of northern France: Sr isotope constraints}

Cary L. ${ }^{1 *}$, Benabderraziq H. ${ }^{2}$, Elkhattabi J. ${ }^{2}$, Gourcy L. ${ }^{1}$, Parmentier M. ${ }^{3}$, Picot J. ${ }^{3}$, Khaska, M. ${ }^{4}$, Laurent $A^{1}$., Négrel Ph. ${ }^{1}$

${ }^{1}$ BRGM (French Geological Survey), 3 av. C. Guillemin, BP 36009, 45060 Orléans Cedex 2, France

${ }^{2}$ University of Lille 1, Polytech'Lille, Laboratoire de Génie Civil et Géo-Environnement LGCgE, Lille, France

${ }^{3}$ BRGM, Synergie Park, 6 ter, rue Pierre et Marie Curie, 59260 LEZENNES

${ }^{4}$ GIS Laboratory, University of Nîmes, Georges Besse Scientific Park, Georges Besse street 150, Nîmes cedex 1, 30035, France

*Corresponding author: Tel. +33(0)238643260. E-mail: I.cary@brgm.fr

Abstract

Groundwater at the southern and eastern edges of France's Paris Basin has a selenium content that at times exceeds the European Framework Directive's drinking-water limit value of $10 \mu \mathrm{g} / \mathrm{L}$. To better understand the dynamics of the Chalk groundwater being tapped to supply the city of Lille and the Se origins, we used a combination of geochemical and isotopic tools. Strontium isotopes, coupled with $\mathrm{Ca} / \mathrm{Sr}, \mathrm{Mg} / \mathrm{Sr}$ and $\mathrm{Se} / \mathrm{Sr}$ ratios, were used to identify the main groundwater bodies and their mixings, with the $\mathrm{Mg} / \mathrm{Sr}$ ratio constraining a ternary system. Groundwater in the agricultural aquifer-recharge zone represents a first endmember and displays the youngest water ages of the catchment along with the highest strontium isotopic signature (0.7084) and low Se contents. Anaerobic groundwater constitutes a second major end-member affected by water-rock interactions over a long residence time, with the lowest strontium isotopic signature (0.7079) and the lowest Se content, its low SF6 content confirming the contribution of old water. Se-rich groundwater containing up to $30 \mu \mathrm{g} / \mathrm{L}$ of Se represents a third major end-member, with an intermediate $\mathrm{Sr}$ isotopic ratio, and is mainly constrained by the clayey Se-rich formation overlying the Chalk aquifer. The spatial and temporal Se variability in the groundwater is clearly linked to the presence of this formation identified as Tertiary and also to the hydrological conditions; 
saturation of the Se-rich clays by oxygenated groundwater enhances Se mobility and also $\mathrm{Sr}$ adsorption onto the clays. This multi-tool study including $\mathrm{Sr}$ isotopes successfully identified the Se origins in the aquifer and has led to a better understanding of the regional mixing and processes affecting the Chalk groundwater.

\section{Introduction}

High concentrations of selenium (Se) in both surface and groundwaters over the past 30 years have emerged as a major issue world-wide. Se, which occurs naturally as a trace constituent in geologic formations (e.g. Cretaceous black shale in the USA (Kulp and Pratt, 2004; Tuttle et al., 2014a) and associated soils, is currently contaminating watersheds in mining areas (Chuncai et al., 2014; Liu et al., 2013; Vengosh et al., 2013), irrigated alluvial valleys (Bailey et al., 2013; Bailey et al., 2012; Bajaj et al., 2011; Deverel and Gallanthine, 1989; Dhillon and Dhillon, 2003; Gates et al., 2009; Tuttle et al., 2014b), wetlands (Zawislanski et al., 2001; Zhang et al., 2012), and sediments (Beisner et al., 2009; Guan and Martin, 1991; Masscheleyn et al., 1990; Oremland et al., 1989)...

Se is a non-metallic element of both nutritional and toxicological importance, but the window between its beneficial contribution to health and its toxic contribution (from excess to deficiency) is very narrow and the safety margin is unknown (Vinceti et al., 2009). Barron et al. (2012) showed that the main human Se inputs come from drinking water in regions where the groundwater has a high Se level. For the purpose of health control, the Water Framework Directive (2000/60/EC) defines an Se threshold value of $10 \mu \mathrm{g} / \mathrm{L}$ for human consumption. Nevertheless, there is no consensus on what is an appropriate standard of Se intake and Vinceti et al. (2013) have reaffirmed the need for a reassessment of the safe upper limit of selenium in drinking water.

Analyses of some groundwater bodies at the southern and eastern edges of France's Paris Basin over the past decade have shown a high Se content (Fig. 1) which raises concern as regards groundwater and tap-water quality. The high Se content in the Paris Basin is related mainly to the presence of Eocene, mainly Ypresian, and Oligocene formations (Chabart et al., 2006; Gourcy et al., 2011). The Ypresian formations were deposited according to various marine transgressions and regressions, and are made of limestones, clays, carbonated sands and fluvial deposits rich in organic matter. The Oligocene formations are essentially made of sands. In the Lille area (northeastern France), a high Se spatial variability has been observed within the well fields since 2000; in 2012, the Se range was between 0.04 to 30 
$\mu \mathrm{g} / \mathrm{L}$. This has resulted in water operators no longer exploiting the most Se-contaminated wells.

The aim of the present study is to understand the interactions between different water bodies and to better assess the origins of the Se, given the constraint of the high pumping rates in the four studied well fields located in an agricultural, urban, and former industrial region southwest of Lille (Fig. 2). The temporal and spatial heterogeneities of the groundwater chemistry of four well fields have been documented along with a regular monthly monitoring. The results were examined in terms of major-element, $\mathrm{Sr}$ and Se concentrations, $\mathrm{H}, \mathrm{O}$ and $\mathrm{Sr}$ isotopes, and chlorofluorocarbon (CFC) and sulphur hexafluoride (SF6) measurements. Our first objective was to understand the spatial disparities in the $\mathrm{Sr}$ isotopic signatures and $\mathrm{Sr}$ and Se contents, both in the regional Chalk aquifer and also more locally at well scale. Our second objective was to investigate anthropogenic and lithological influences on the groundwater chemistry. Groundwater sources of Se from recharge sources and water pathways within the basin were traced using $\mathrm{Sr}$ isotopic signatures. This approach leads to a better understanding of the global functioning of the Chalk aquifer and confirms that $\mathrm{Sr}$ isotopes can be valuably used for tracing the origins and mobilization of $\mathrm{Se}$ in the Chalk aquifer.

\section{Geological and hydrogeological context}

In the study area, the stratigraphic succession of the Paris Basin begins with a highly faulted, more-or-less dolomitic, several hundred meter thick sequence of Lower Carboniferous limestone and calcareous shale. This is overlain by marly Cenomanian chalk, locally called the "Dièves", resulting from the Cretaceous transgression (Fig. 2). The "Dièves" is followed by a thick deposit of Turonian marly limestone that evolves upward to white and grey flintbearing Turonian and Senonian Chalk with phosphate beds. The unconformably overlying Tertiary formations comprise the Louvil Clay (Lower Landenian, 9-12 m thick), the Ostricourt Sand (Upper Landenian, 25-30 m thick), and the Flandres Clay (Ypresian, 10-15 m thick). It is the Tertiary formations throughout the Paris-London Basin that confine the underlying Chalk aquifer, inducing a redox boundary (Edmunds and Smedley, 2000; Elliot et al., 1999; Kloppmann et al., 1996; Smedley and Edmunds, 2002). Quaternary loess (pre-Weichselian and Weichselian) covers practically the entire basin.

Given the structural context, a new hypothesis is suggested for the age of the clays present at 5-15 m depth in the Wells A11 to A15 area (Fig. 2), newly interpreted as Early Tertiary (Thanetian) instead of Quaternary as described in the geological database. These clays were 
protected from erosion through fault activation (Lutetian, Bartonian and Oligocene) prior to the Quaternary. The last $5 \mathrm{~m}$ are constituted by the quaternary alluvium of the Deûle River, mainly comprising heterogeneous sandy clayey deposits.

The Dieves marl forms the impermeable base of the Chalk aquifer (Fig. 2). The TuronianSenonian Chalk constitutes the Chalk aquifer encountered at 10-50 m depth, favored by the presence of highly permeable horizons with open fissures mainly found at 10-15 m depth (Caous, 2003). The fissures and stratification joints in the Chalk close with depth, resulting in a significant decrease in rock permeability. The inter-annual average rainfall is $689 \mathrm{~mm}$ with an effective rainfall of $177 \mathrm{~mm}$, and the main recharge area is close to Emmerin (Caous, 2003). The groundwater of the Chalk aquifer circulates in the fault network, which is highly developed in the valleys where the well fields are sited.

Drinking water for the urban community of Lille (more than 1 million inhabitants) is pumped through four well fields tapping the Chalk aquifer to the southwest of Lille (Fig. 2), i.e. the Emmerin, Houplin-Ancoisne, Les Ansereuilles and Salomé fields. The Deûle River and other small tributaries (Seclin canal, Tortue and Naviette) drain the area and quantitative and qualitative pressures of industrial, urban and agriculture origins occur. Exploitation of the aquifer in the study area decreased from $40-50 \mathrm{Mm}^{3}$ in the $1960-1980$ 's to $30-40 \mathrm{Mm}^{3}$ due to decreased industrial pumping. The potentiometric surface of the Chalk layer is distorted by a cone of depression centered on Les Ansereuilles (Fig. 2). In 1985, around $20 \%$ of the water for Lille came from the Deûle River via the Quaternary alluvium, but the high pumping rate from the Les Ansereuilles well fields has drained this source (Talbot et al., 1985, Bourg et al., 1985).

The Emmerin and Houplin-Ancoisne well fields will be referenced hereafter as E-H.A. The Emmerin well field is constituted by 8 wells located at the top of a WNW-ESE anticline, the thickness of the Cretaceous beds is reduced as shown in the cross section (Fig. 2). The Houplin-Ancoisne well field has 10 wells $(\mathrm{H} 1$ to $\mathrm{H} 10)$ aligned along the Seclin canal, which follows the trajectory of the major NW-SE-trending Seclin Fault, and one offset well $(\mathrm{H} 11)$ (Fig. 2). The Seclin Fault affects the depth of the Chalk (9 $\mathrm{m}$ in Well H4; $6 \mathrm{~m}$ in Well H11). The Chalk groundwater is locally confined below the clayey deposits (present in Well H11). The Les Ansereuilles well field has 27 wells and is parallel to the highly polluted Deûle River. The groundwater, which is unconfined to the southwest of the Deûle, flows northwestward to become confined under the alluvial cover whose thickness locally reaches 15 to $20 \mathrm{~m}$. It is also locally confined in the A11-A15 well area due to the presence of more than $10 \mathrm{~m}$ of clay deposited above the Chalk (Fig.2). In the Salomé well field (17 wells), the Chalk is covered 
with a layer of sandy clayey silt, 1 to $10 \mathrm{~m}$ thick, making the aquifer unconfined, with the groundwater circulating SW to NE with a gradient of $1.5 \%$.

\section{Material and methods}

A first initial sampling and analysis program was carried out in June 2011 in which the geochemistry and strontium isotope ratios were determined for 20 wells all acting as drinking water wells. A second program was a monthly monitoring program over a period of 14 months (2012-2013). It aimed at studying four wells (A13, A24, H4 and S3), yielding a range of Se contents corresponding to the high variability observed in the well fields, and the monitoring of the Deûle River and of its tributaries. Measurements of the physical and chemical parameters (temperature, conductivity, $\mathrm{pH}$, Eh, and dissolved oxygen) were made in situ. The groundwater samples were then filtered in the field at $0.45 \mu \mathrm{m}$. Samples for cations and $\mathrm{Sr}$ isotopes analyses were acidified by $\mathrm{HNO}_{3}$. Samples for anions were stored non acidified.

Analyses of $\mathrm{Ca}, \mathrm{Mg}, \mathrm{Na}, \mathrm{K}$ were carried out by inductively coupled plasma-atomic emission spectroscopy (ICP-AES, Ultima-2 model, Jobin Yvon), and $\mathrm{Cl}, \mathrm{SO}_{4}$, and $\mathrm{NO}_{3}$ by ion chromatography (model DX120, Dionex) in the BRGM laboratory. The accuracy of both techniques was around 5-10\% depending upon the concentration. Selenium and strontium concentrations were measured by inductively coupled plasma mass spectrometry (ICP-MS) (uncertainty $5 \%$ ). Alkalinity was determined by $\mathrm{HCl}$ titration and Gran's method on the sampling day.

Chemical separation of the $\mathrm{Sr}$ was done using an ion-exchange column (Sr-Spec), with a total blank of $0.5 \mathrm{ng}$ for the entire chemical procedure. After chemical separation, $1 / 5$ of the sample was loaded onto a tungsten filament and analysed with a Finnigan MAT 262 multiple collector mass spectrometer. The ${ }^{87} \mathrm{Sr} /{ }^{86} \mathrm{Sr}$ ratios were normalised to an ${ }^{86} \mathrm{Sr} /{ }^{88} \mathrm{Sr}$ ratio of 0.1194 . The reproducibility of the ${ }^{87} \mathrm{Sr} /{ }^{86} \mathrm{Sr}$ ratio measurements was tested through duplicate analyses of the NBS 987 standard and the mean value was $0.710243 \pm 12.10^{-5} \quad(2 \sigma, \mathrm{N}=18)$. The ${ }^{2} \mathrm{H}$ and ${ }^{18} \mathrm{O}$ isotopes of the water molecule were measured on raw water using a Finnigan MAT 252 mass spectrometer with a precision of $0.1 \%$ for $\delta^{18} \mathrm{O}$ and of $0.8 \%$ for $\delta^{2} \mathrm{H}$. The isotopic compositions are plotted on the usual $\delta$-scale in \%o with reference to V-SMOW according to the equation $\delta_{\text {sample }}(\%)=\left(R_{\text {sample }} / R_{\text {standard }}\right)^{*} 1000$, where $R$ is the ${ }^{2} H /{ }^{1} H$ and ${ }^{18} \mathrm{O} /{ }^{16} \mathrm{O}$ atomic ratios. 
Chlorofluorocarbons (CFC-11, CFC-12, CFC-13) and sulphur hexafluoride (SF6) were analysed on raw water sampled in $500 \mathrm{~mL}$ glass bottles using gas chromatography in the Spurenstofflabor laboratory (Germany). The detection limit was close to $10^{-4} \mathrm{pmol}$, allowing the measurement of CFC concentrations down to $0.01 \mathrm{pmol} / \mathrm{L}$ and SF6 concentrations to 0.1 $\mathrm{fmol} / \mathrm{L}$. The reproducibility was about $\pm 5 \%$ for water samples. The calculations follow the programs developed by the International Atomic Energy Agency (IAEA, 2006). The CFC-11 and CFC-12 were used mainly for refrigeration and air-conditioning, while CFC-113 was used as a solvent and SF6 for its electrical and thermal insulation properties. CFC and SF6 tools are increasingly being used to date recent groundwater components allowed the apparent groundwater ages to be estimated (Darling et al., 2012; Gooddy et al., 2006; Gourcy and Brenot, 2011).

For the solid samples, flint and white Chalk were sampled from the Emmerin quarry, and the Tertiary deposits (Landenian Ostricourt Sand and Ypresian Flandres Clay) and Quaternary silt were sampled from the Templeuve quarry. Cuttings of sediments were done by drilling with a helical auger without fluid addition close to wells A13, H4, H11 and S3 till reaching the chalk. After total rock dissolution by classical tri-acid mineralization, the chemical composition of the major and trace elements was measured by ICP-AES. The strontium isotope composition of solid samples (except sediments) was obtained after simple leaching with deionized water and analysed with a Finnigan MAT 262 multiple collector mass spectrometer (Négrel and Petelet-Giraud, 2005).

\section{Results}

The concentrations of the major elements, Se and $\mathrm{Sr}, \delta^{2} \mathrm{H}$ and $\delta^{18} \mathrm{O}$, and ${ }^{87} \mathrm{Sr} /{ }^{86} \mathrm{Sr}$ are given under Supporting Information in Table 1. The compositions of the rocks are presented under Supporting information in Table 2.

\subsection{Groundwater chemistry}

The groundwater in the E-H.A area showed the lowest $\mathrm{Na}, \mathrm{Mg}$, and $\mathrm{HCO}_{3}$ concentrations, with $\mathrm{Sr}$ close to the average concentration in the Deûle River (Supporting Information Table 1). Conversely, the groundwater in Well A26 and its neighboring wells $A 25, A 27$ and $A 28$ in the Les Ansereuilles area, stood out in having the highest concentrations in $\mathrm{Cl}$ (1.9 to 3 $\mathrm{mmol} / \mathrm{L}$ ), $\mathrm{Na}, \mathrm{Mg}, \mathrm{HCO}_{3}$ and $\mathrm{Sr}$, and the lowest $\mathrm{Ca}$ content similar to that measured in the Deûle River (around $3 \mathrm{mmol} / \mathrm{L}$ ). The Sr concentration in Well A26 was 10 times higher than 
in the E-H.A group. The surface water of the Deûle catchment displayed a low $\mathrm{Cl}$ concentration ranging from 1.7 to $2.1 \mathrm{mmol} / \mathrm{L}$.

The Se content has been measured for control for two decades and high Se content in the groundwater was observed since the 2000's. Sixteen of the 27 wells $(60 \%)$ in Les Ansereuilles and 8 of the 11 wells $(70 \%)$ in Houplin-Ancoisne displayed Se contents $>10$ $\mu \mathrm{g} / \mathrm{L}(0.13 \mu \mathrm{mol} / \mathrm{L})$. Interestingly, the groundwater of the depressed area in Les Ansereuilles displayed a varying Se content ranging from below the quantification limit in Well A14 to 30 $\mu \mathrm{g} / \mathrm{L}(0.38 \mu \mathrm{mol} / \mathrm{L})$ in Well $A 12$ where pumping was subsequently abandoned. Consequently, we selected the nearby $(100 \mathrm{~m})$ pumped Well $\mathrm{A} 13$ for the monitoring program. Any Se in the groundwater sampled from wells $A 26$ and A14 was below the detection limit. Well A24, with a range of Se content of $10-15 \mu \mathrm{g} / \mathrm{L}(0.12-0.19 \mu \mathrm{mol} / \mathrm{L})$ that was inferior to the drinking water standard, was monitored as a reference. In the Salomé well field, 5 out of the 17 wells displayed a Se content higher than the drinking water standard, whereas only one of the nine wells in the Emmerin well field returned an Se concentration of $>10 \mu \mathrm{g} / \mathrm{L}$.

Monthly regular sampling of the groundwater displayed evolutionary trends in the major- and trace-element concentrations for wells $\mathrm{A} 13, \mathrm{H} 4, \mathrm{~A} 24$ and S3. With wells $\mathrm{A} 13$ and $\mathrm{H} 4$, this basically followed variations in the hydrological conditions(high rainfalls in April (92 $\mathrm{mm}$ ), June (82 mm), July (150 mm), and October (132 mm) 2012). For Well A13, the Sr content varied from 11.5 to $18.0 \mu \mathrm{mol} / \mathrm{L}$ respectively in July and April 2012, and the Se content varied significantly between $0.16 \mu \mathrm{mol} / \mathrm{L}(12.8 \mu \mathrm{g} / \mathrm{L})$ in January 2013 and $0.4 \mu \mathrm{mol} / \mathrm{L}(32 \mu \mathrm{g} / \mathrm{L})$ in July 2012, with an average value of $0.27 \mu \mathrm{mol} / \mathrm{L}$. Well $\mathrm{H} 4$ also displayed varying Se concentrations, although with a lower range (0.06 to $0.17 \mu \mathrm{mol} / \mathrm{L})$ and a slightly lower average value $(0.25 \mu \mathrm{mol} / \mathrm{L}$ for 2012). Monitored as a reference, Well A24 showed no significant variation in $\mathrm{Sr}$ and Se concentration (respectively mean of 7.5 and $0.16 \mu \mathrm{mol} / \mathrm{L}$ ). Similarly, Well S3 in Salomé displayed only a very low variation in its chemistry (respectively mean of 15 for $\mathrm{Sr}$ and $0.07 \mu \mathrm{mol} / \mathrm{L}$ for $\mathrm{Se})$.

\section{$4.2 \delta^{18} \mathrm{O}, \delta^{2} \mathrm{H}$, and ${ }^{87} \mathrm{Sr} /{ }^{86} \mathrm{Sr}$ variations in the surface water and groundwater}

For the surface water, the stable isotopes ranged from $-7.76 \%$ o to $-4.8 \%$ for $\delta^{18} \mathrm{O}$ and from $51.8 \%$ to $-35.6 \%$ for $\delta^{2} \mathrm{H}$ (see Supporting Information Table 1). The average $\delta{ }^{18} \mathrm{O}$ and $\delta$ ${ }^{2}$ Hdata for the Deûle River ranged respectively from $-6.84 \%$ and $-46.50 \%$ in winter to $-6.2 \%$ o and $-44.06 \%$ in summer. The values for the Seclin canal and the Deûle, Naviette and Tortue river waters were particularly enriched in $\delta^{2} \mathrm{H}$ and $\delta^{18} \mathrm{O}$ during the 2012-2013 winter. 
For the groundwater, the $\delta^{18} \mathrm{O}$ and $\delta^{2} \mathrm{H}$ from the initial program fell respectively in the range of $-7 \%$ o to $-5.64 \%$ and $-47.9 \%$ to $-44.2 \%$ (Fig. 3). The groundwater in Well A26 displayed the lowest $\delta^{18} \mathrm{O}$ and $\delta^{2} \mathrm{H}$ values. Apart from the February and March 2012 data, the monitoring in wells $\mathrm{A} 13, \mathrm{~A} 24, \mathrm{~S} 3$, and $\mathrm{H} 4$ showed only a narrow range of $\delta{ }^{18} \mathrm{O}$ and $\delta{ }^{2} \mathrm{H}$ signatures; the differences during the sampling period were less than $0.6 \%$ for $\delta^{2} \mathrm{H}$ and $0.07 \%$ for $\delta^{18} \mathrm{O}$.

The strontium isotopic signatures, only analysed for samples from the initial program, displayed significant spatial disparities. The highest values (0.70840-0.70845) were recorded in Emmerin and Houplin-Ancoisne groundwater (wells E10, E5, E7, H4, H9), whereas the lowest value (0.70789) was recorded from the confined groundwater of Well A26. All the other wells displayed intermediate $\mathrm{Sr}$ isotopic values.

\subsection{CFCs and SF6 contamination}

All the groundwater samples were contaminated by CFCs and SF6 at various levels. All the groundwater samples were contaminated by CFCs and SF6 at various levels. The groundwater in wells $\mathrm{A} 3, \mathrm{~A} 4, \mathrm{H} 4, \mathrm{H} 6$, and $\mathrm{S} 3$ was found to have higher $\mathrm{CFC}-12$ concentrations than modern air-equilibrated water (2.97 pmol/L of CFC-12) (Gooddy et al., 2006), making CFC-12 ineffective as a groundwater dating tool. Moreover, CFCs may possibly be reduced within the confined parts of aquifers. Therefore, only SF6 data were used for dating.

The initial program showed that SF6 concentrations in the groundwater varied between $0.7 \pm 0.1 \mathrm{fmol} / \mathrm{L}$ (Well A14) and 3.6 $\pm 0.4 \mathrm{fmol} / \mathrm{L}$ (Well S8), the latter being above modern values (2.3 fmol/L, Gooddy et al., 2006) (Supporting information, Table 1). The group most contaminated by SF6 comprises wells $\mathrm{E} 10, \mathrm{H} 4, \mathrm{H} 6$ and $\mathrm{H} 9$, with concentrations equaling that of modern air-saturated water. Samples showing a higher SF6 concentration than air suggest contamination; Well A23 was probably contaminated by the nearby treatment plant. The wells located in the depressed area in the northeastern part of the Les Ansereuilles catchment displayed a relatively low contamination $(0.7$ and $0.9 \pm 0.1 \mathrm{fmol} / \mathrm{L}$ respectively for A14 and A12. The lowest concentrations were found in the confined Well A26 with $0.2 \pm 0.1$ fmol/L for SF6.

SF6 concentrations measured during the monitoring program were high in Well A24 (from 1.5 to $2.6 \mathrm{fmol} / \mathrm{kg}$ ), and even higher in Well H4 (from 1.7 to $3.3 \mathrm{fmol} / \mathrm{kg}$, mean of $2.1 \mathrm{fmol} / \mathrm{kg}$ ). Lower, but varying, SF6 concentrations were measured in Well A13 (from 0.9 to $1.7 \mathrm{fmol} / \mathrm{kg}$, 
with a mean of $1.2 \mathrm{fmol} / \mathrm{kg}$ ). Well S3, however, displayed very high SF6 concentrations varying between 1.8 and $4.7 \mathrm{fmol} / \mathrm{kg}$, indicating possible contamination.

\section{Discussion}

The spatial disparities observed in the element concentrations and ${ }^{87} \mathrm{Sr} /{ }^{86} \mathrm{Sr}$ values for the wells could reflect varied water pathways, varied recharge of the groundwater bodies, and varied land uses in the catchment.

\subsection{Aquifer recharge, surface water / groundwater interactions, and spatial variability}

The stable isotope variations in the groundwater are due mainly to (i) natural variations in the isotopic composition of the rainfall, (ii) the mixing with pre-existing waters, and (iii) the influence of evaporation during percolation through the soil or the unsaturated zone. CFCs from the atmosphere dissolve in water according to their Henry's Law solubilities at the recharge temperature (Plummer and Busenberg, 1999) which, in the study area, can be estimated at $12{ }^{\circ} \mathrm{C}$ based on the regional mean annual air temperature and can be used as age tracers. Knowing that the average altitude of the sampling points is around 20 m.a.s.l., the error in the estimation of apparent ages due to the uncertainty of point elevation is very low. The uncertainty due to an error in estimating the recharge temperature is $5 \%$ using the binary mixing model.

The $\delta^{18} \mathrm{O}$ and $\delta^{2} \mathrm{H}$ values of the groundwater samples collected in the four well fields lie within their $95 \%$ uncertainty envelope between the global meteoric water line (GMWL) and the meteoric line at Trier (Germany), , which is the closest locality with sufficient data from the Global Network of Isotopes in Precipitation (GNIP) (Craig, 1961) (Fig. 3). It supports the idea that the groundwater most probably comes from present-day precipitation; the groundwater and surface-water samples showed only a narrow range of $\delta^{18} \mathrm{O}$ and $\delta^{2} \mathrm{H}$ signatures, especially when compared to the rain input throughout France in which $\delta^{18} \mathrm{O}$ may vary from $-16 \%$ to $0 \%$ and $\delta^{2} \mathrm{H}$ from $-120 \%$ to $0 \%$ (Millot et al., 2010). This narrow range reflects groundwater mixing over at least one hydrologic cycle with buffering of the different water inputs (Huddard et al., 1999).

The Emmerin groundwater samples plot at the intersection between the local Trier meteoric line and a 4.5 slope line, and displayed the most depleted values of the unconfined aquifer. The Les Ansereuilles groundwater signatures showed a spatial isotopic variability. Except for 
Well A26, this variability corresponds exactly to the range of the summer and winter isotopic means of the Deûle River water. Knowing that evaporation lines have a slope between 3.5 and 6.0 as function of local atmospheric humidity (Gat, 1981), this means that both the surface water and groundwater include slightly evaporated water. All tributaries to the Deûle River receive surface runoff from agricultural and industrial-commercial areas. The river water samples display a mixing with both rain water and stagnant water that has evaporated within the remaining wetlands where water renewal is limited; this is clear in the water from the Seclin canal which displays the highest enrichment. The fractionation trend in the groundwater can also be explained by partial evaporation of the water before infiltration into the aquifer, as has already been showed for the Chalk aquifer in Champagne (Vachier et al., 1987). Interestingly, data acquired in the 1980's from the same Chalk aquifer in the Lille region were close to the GMWL and did not display an evaporative contribution (Bernard et al., 1981; Garnier, 1976; Simon, 1986). The appearance of this rather recent evaporative contribution may be linked to a change in the recharge contribution, i.e. the intense pumping rates of the last 30 years may have triggered either (i) leaching of the entire unsaturated profile, thus soliciting a higher contribution of recharge water, or (ii) a contribution of Deûle River water, both integrating an evaporative component. The groundwater of Well A26 was the most depleted in $\delta^{18} \mathrm{O}(-7.2 \%)$ and plotted on the local meteoric line. It can be considered as having the lowest influence from surface and/or alluvial water.

The absence of variation in the stable isotopic composition of the water over time from the monitored wells suggests that the groundwater can buffer the seasonal variations in rainwater input (Table 2 in Supporting information). Measurements made in February and March 2012 make up a distinct group in that they showed $\delta{ }^{18} \mathrm{O}$ enrichment with constant $\delta$ ${ }^{2} \mathrm{H}$. These data may most surely issue from a mixing with an evaporated component that could originate from evaporated recharge water. These values were not recorded again during the monitoring program, especially in winter 2013, and may have originated from a particular phenomenon linked to the hydrodynamic conditions. Vvery low piezometric levels were reached during February and March 2012, which resulted in the operators temporarily halting the pumping.SF6 data were used to evaluate apparent ages through applying a binary mixing model. This model considers old water before 1950 (pre-tracer CFC-free) and young water with an age between 1985 and Present. It is one of the simplest models to consider, and has already been used with success in the Chalk aquifer (Gooddy et al., 2006; Gourcy and Brenot, 2011). In some wells (S8 and H9), SF6 contamination made the apparent age estimates doubtful (Supporting Information Table 1). At site scale, the apparently youngest groundwater (mean modern fraction of $91 \%$ for Emmerin and $99 \%$ for 
wells $\mathrm{H} 4, \mathrm{H} 6$ and $\mathrm{H} 9$ ) thus reflect the local role of recharge in the area which can be highly contaminated by present or past activities. The modern fraction of Well H11 (72\%) was significantly lower, which may be explained by the regional Seclin Fault, used to advantage by water operators, possibly giving rise to mixing with pre-tracer water flowing along the fault.

In the Les Ansereuilles area, the modern water fraction for Well A26 is only $10 \%$, thus confirming a large contribution of old water. SF6 data for the groundwater of Well A23, close to a sewage plant, displayed a very recent contribution of recharge water (99\%). Surprisingly, two neighboring wells (A17 and A18) displayed very different modern fractions of $54 \%$ and $92 \%$, respectively. The presence of a fault having a screen role in the Chalk between wells A17 and A22 may induce mixing with old water in Well A17. The wells in the A11-A15 area of Les Ansereuilles displayed a smaller modern fraction (35\% for $A 12$ and $65 \%$ for $A 14$ ). Although the Deûle River water was not analysed, we can assume that its SF6 concentrations are close to or above modern air-saturated water (Gooddy et al., 2006).

With the monitoring program, the modern fraction of Well A24 groundwater was almost constant (between $66 \%$ and $74 \%$, average of $70 \%$ ); this would be equivalent to approximately 3 parts modern water to 1 part pre-tracer water when considering a binary mixing model. For Well $\mathrm{A} 13$, the modern fraction was higher during the winter months, varying from 34\% in May 2012 to $65 \%$ in February 2012 (average of 46\%), apart from the July measurement which gave $53 \%$. A seasonal variation was also noted in Well $\mathrm{H} 4$, with a higher modern fraction in winter, i.e. $65 \%$ in June 2012 to $9-99 \%$ in the $2012-2013$ winter. Well S3 displayed the highest contribution of modern water (from $75 \%$ in May 2012 to $100 \%$ in the 2012-2013 winter). Knowing that the Tertiary and Quaternary sediments (T-Q) can be rather thin in Salomé, fast transfers could dominate.

\subsection{Groundwater types and origins}

The chemical facies of the groundwater samples were of a relatively homogeneous Ca-Mg$\mathrm{HCO}_{3}$ type. Carbonate dissolution in the Chalk aquifer leads to the release of $\mathrm{Ca}, \mathrm{Mg}$ and $\mathrm{Sr}$ into the water, justifying the use of the bivalent $\mathrm{Ca} / \mathrm{Sr}$ and $\mathrm{Mg} / \mathrm{Sr}$ ratios as indicators of waterrock interaction; these are directly related to the groundwater residence time (Edmunds et al., 1987). The chemistry of both the groundwater and the solids are shown in the following figures (4 to 8 ).

The groundwater type evolves between two facies: (1) the E-H.A type (excluding Well H11) with low $\mathrm{Na}, \mathrm{Mg}$, and $\mathrm{Sr}$ concentrations indicating a relatively short residence time with little 
water-rock interaction, and (2) the confined type, represented by the groundwater of Well A26 with its high $\mathrm{Na}, \mathrm{Mg}$, and $\mathrm{Sr}$ concentrations indicating a long residence time with greater water-rock interaction (Edmunds et al., 1987) (Fig. 4). The groundwater showed higher Ca, $\mathrm{Mg}$, and $\mathrm{Sr}$ concentrations than would be expected from an ideal mixing with seawater and local rainwater. The dots in all the diagrams plot above the seawater dilution line, except for some E-H.A wells that showed a slight $\mathrm{Na}$ depletion. Since no evaporites have been described in the study region, the groundwater $\mathrm{Cl}$ can only originate from rainfall recharge and human activities, mainly through the application of fertilizers and wastewater inputs (Widory et al., 2004). The abundance of $\mathrm{Ca}$ due to carbonate dissolution masks the $\mathrm{Ca}$ excess that could be combined with the $\mathrm{Na}$ deficit due to cationic exchange with the clays in the alluvial sediment above the Chalk. $\mathrm{Sr}$ and $\mathrm{Mg}$ gave similar variations when plotted against $\mathrm{Cl}$, confirming the similarity between the behavior of $\mathrm{Mg}^{2+}$ and $\mathrm{Sr}^{2+}$ (Dogramaci and Herczeg, 2002).

\subsection{Sr isotope systematics for defining lithological controls on groundwater chemistry}

The primary sources of $\mathrm{Sr}$ in groundwater are atmospheric input, dissolution of $\mathrm{Sr}$-bearing minerals, and anthropogenic input. The concentration of $\mathrm{Sr}$ across the aquifer is usually closely related to the congruent and incongruent reactions of calcite. The biogenic calcite of coccoliths, which constitute the main phase of the Chalk, dissolves and brings $\mathrm{Mg}$ and $\mathrm{Sr}$ as trace elements to the groundwater, whilst a purer calcite re-precipitates (Edmunds et al., 1987). The highest Sr concentration found in the confined part of the Chalk aquifer (53.8 $\mu \mathrm{mol} / \mathrm{L})$ made water just below strontianite and celestite saturation $(\mathrm{SI}=-0.75$ and -0.97$)$.

Strontium-isotope ratios vary in nature because one of the strontium isotopes $\left({ }^{87} \mathrm{Sr}\right)$ is formed by the radioactive decay of the naturally occurring element rubidium $\left({ }^{87} \mathrm{Rb}\right)$. The ${ }^{87} \mathrm{Sr} /{ }^{86} \mathrm{Sr}$ ratio is classically used as a tracer of water-rock interaction (Blum et al., 1994; Négrel et al., 2001). Strontium isotopic signatures in groundwater are not dependent on dilution processes (e.g. hydrological conditions) and so enable sources of dissolved $\mathrm{Sr}$ to be traced. Here normalized-Sr ratios, the $\mathrm{Ca} / \mathrm{Sr}$ against the $\mathrm{Mg} / \mathrm{Sr}$ ratios, are first investigated for both solids and the groundwater (Fig. 5), as well as the ${ }^{87} \mathrm{Sr} /{ }^{86} \mathrm{Sr}$ ratio against the $\mathrm{Ca} / \mathrm{Sr}, \mathrm{Mg} / \mathrm{Sr}$ and $\mathrm{Se} / \mathrm{Sr}$ ratios (Fig. 6, 7,and 8) where mixing is represented by straight lines (Faure, 1986).

The $\mathrm{Ca} / \mathrm{Sr}$ and $\mathrm{Mg} / \mathrm{Sr}$ ratios indicate a mixing of groundwater with different chemistries linked to lithological variations, especially between the carbonate and silicate poles, the presence or absence of dolomite, and variations in residence time. In the $\mathrm{Ca} / \mathrm{Sr}$ vs. $\mathrm{Mg} / \mathrm{Sr}$ diagram for solids (Fig. 5a), samples of the regional geological formations constitute two contrasting end- 
members: (1) the local Chalk end-member with high $\mathrm{Ca} / \mathrm{Sr}(1500-1620 \mathrm{~mol} / \mathrm{mol})$ and low $\mathrm{Mg} / \mathrm{Sr}(18 \mathrm{~mol} / \mathrm{mol}$ ) ratios, and (2) the T-Q silicate end-member with low $\mathrm{Ca} / \mathrm{Sr}$ and high $\mathrm{Mg} / \mathrm{Sr}$ ratios. The $\mathrm{Mg} / \mathrm{Sr}$ ratio of the Ostricourt sand evolved from 209 at the bottom to 1260 $\mathrm{mol} / \mathrm{mol}$ at the top, showing enrichment in $\mathrm{Mg}$ probably due to leachates from the Upper Ypresian clay.

Within the four studied wells, the chemical composition of the solids evolved clearly between these two lithological end-members. With similar $\mathrm{Mg} / \mathrm{Sr}$ values, the sediment of Well $\mathrm{H} 4$ showed a higher $\mathrm{Ca} / \mathrm{Sr}$ ratio than of Well $\mathrm{A} 13$, the latter being almost dominated by clay whereas the former comprises successive horizons of sand and clay, in which Chalk grains can be found, inherited from alternating Quaternary erosion/sedimentation.

In the $\mathrm{Ca} / \mathrm{Sr}$ vs. $\mathrm{Mg} / \mathrm{Sr}$ diagram for water (Fig. $5 \mathrm{~b}$ ), the $\mathrm{Ca} / \mathrm{Sr}$ and $\mathrm{Mg} / \mathrm{Sr}$ ratios of the studied groundwater were in the range of the Chalk groundwater of the London Basin in Berkshire (respectively 17-5300 and 14-130; Edmunds et al., 1987), but displayed a larger range than for the Chalk aquifer of the Somme region (respectively 700-1200 and 30-110; Négrel and Petelet-Giraud, 2005) or at La Bassée (respectively 700-1300 and 20-50; (Gourcy and Brenot, 2011). At the study site, three main end-members are indicated to explain the chemical composition of the groundwater:

(1) The E-H.A group, with the highest $\mathrm{Ca} / \mathrm{Sr}$ ratios that could result from a mixing between the two lithological poles mentioned above.

(2) The groundwater of the confined area represented by Well A26 displayed the lowest $\mathrm{Ca} / \mathrm{Sr}$ and $\mathrm{Mg} / \mathrm{Sr}$ ratio values. The ratios were similar to those measured in the confined parts of the Chalk aquifer in Berkshire (Edmunds et al., 1987) and also to those measured in the confined Carboniferous groundwater sampled nearby (Gourcy and Crastes de Paulet, 2012).

(3) The groundwater from Well A12 with the highest $\mathrm{Mg} / \mathrm{Sr}$ ratios plotted correctly on a mixing line between the Chalk and the T-Q pole. Well A17 displayed a similar composition than that of Well A12.

All the groundwater samples showed a trend from low (10) to high (1000) $\mathrm{Mg} / \mathrm{Sr}$ ratios between the Well A26 and Well A12 type end-members. They clearly displayed a varied contribution of confined groundwater, which is consistent with the proximity of the Tertiary formations as well as with the piezometric fluxes. The $\mathrm{Mg} / \mathrm{Sr}$ ratio successfully discriminates 
mixing of groundwater from Les Ansereuilles with old groundwater with a long residence time enhancing the water-rock interactions.

Surface water mixing with the groundwater is also possible, given the similar value of the $\mathrm{Ca} / \mathrm{Sr}$ ratio in the groundwater of the southwestern part of the Les Ansereuilles catchment area (wells A23, A24 [annual mean], A17, A18 and A3) and the surface water of the Deûle River. The Deûle River may indeed represent an end-member of the system due to its contribution $\left(900 \mathrm{~m}^{3} / \mathrm{d}\right)$ to the groundwater.

Significant monthly variations were recorded for the $\mathrm{Ca} / \mathrm{Sr}$ and $\mathrm{Mg} / \mathrm{Sr}$ molar ratios in monitored wells A13 and A24 whereas they were slightly less for wells H4 and S3 (Supporting Information Table 1). This indicates a change in the water chemistry of the four well fields during the period of monitoring resulting from degrees of mixing between groundwater originating from the confined and unconfined parts of the aquifer.

In the ${ }^{87} \mathrm{Sr} /{ }^{86} \mathrm{Sr}$ vs. Ca/Sr diagram (Fig. 6), a global trend is seen between two contrasted poles with a large $\mathrm{Ca} / \mathrm{Sr}$ and ${ }^{87} \mathrm{Sr} /{ }^{86} \mathrm{Sr}$ variation: (1) the E-H.A groundwater (E10, E5, E7, H4, $\mathrm{H} 9$ ) with the high ${ }^{87} \mathrm{Sr} /{ }^{86} \mathrm{Sr}$ values (0.70840-0.70845), and (2) the A26 confined groundwater with the lowest strontium isotopic signature (0.70789). The $\mathrm{Sr}$ isotopic compositions of these two end-members correspond to lithological signatures that have been identified in a ternary system at regional scale: (1) Cretaceous Chalk leachates (0.70735) related to the oxic conditions, and (2) the Well A26 type in anoxic conditions, and (3) the T-Q pole with the very high ${ }^{87} \mathrm{Sr} /{ }^{86} \mathrm{Sr}$ ratios of Ypresian (0.70977) and Quaternary (0.71-0.73; (Drouet et al., 2005)) rock leachates.

The leachate signature of the Chalk is similar to that of the UK Turonian Chalk $(0.7074)$ (McArthur et al., 1993). The base of the Ostricourt Sand displayed an intermediate ${ }^{87} \mathrm{Sr} /{ }^{86} \mathrm{Sr}$ ratio $(0.70886)$ which could result from the infiltration of leachate water from the clayey Upper Ypresian and Quaternary formations. The strontium isotopic values of the groundwater are similar of those of La Bassée (Gourcy and Brenot, 2011).

A deviation towards high ${ }^{87} \mathrm{Sr} /{ }^{86} \mathrm{Sr}$ is observed and the strontium isotopic signature of Well A26 groundwater was slightly more radiogenic than both the local Chalk rock and the Chalk groundwater in Berkshire; a deviation that had already been identified in the Chalk aquifer (Brenot et al., 2008; Gourcy and Brenot, 2011; Négrel and Petelet-Giraud, 2005). The strontium isotopic signature of the local Chalk aquifer can be explained by (1) the mixing of the various Tertiary weathering products with the Chalk component that presents a low $\mathrm{Sr}$ isotopic signature, and (2) the major impact of carbonate dissolution on the isotopic signature 
of the Chalk aquifer due to the dissolution kinetics of carbonates being higher than that clay or $\mathrm{K}$ - and $\mathrm{Rb}$-bearing minerals (illite and muscovite with high isotopic ratio).

The confined groundwater of Well A26 may integrate a slight high ${ }^{87} \mathrm{Sr} /{ }^{86} \mathrm{Sr}$ component from the overlying Sr-radiogenic T-Q silicate end-member. Similarly, in Berkshire, the strontium isotopic variation measured in the Chalk aquifer ( 0.7071 to 0.7074$)$ could also be explained by leaching of the overlying Eocene Reading Beds (sand, loam, clay...) that may also present more radiogenic values.

The ${ }^{87} \mathrm{Sr} /{ }^{86} \mathrm{Sr}$ ratios of E-H.A groundwater, being higher than those of Well A26, may well be explained by a contribution of high ${ }^{87} \mathrm{Sr} /{ }^{86} \mathrm{Sr}$ from fertilizers (Brenot et al., 2008; Vitoria et al., 2004). Correlating $\mathrm{NO}_{3}$ and $\mathrm{Sr}$ shows that supplementary $\mathrm{Sr}$ with a more radiogenic signature was provided to the system in the E-H.A recharge area where a high nitrate content from the use of fertilizers was measured (Cary et al., 2013). The E-H.A pole is in line with the A26-A12 correlation.

In the fault depression of the northeastern part of the Les Ansereuilles catchment area, wells $\mathrm{A} 14$ and $\mathrm{A} 12$ yielded $\mathrm{Ca} / \mathrm{Sr}$ and strontium isotopic ratios that represented the entire variation range of Les Ansereuilles (apart from Well A26). They constitute two clear local endmembers among which all points of Les Ansereuilles (minus Well A26) were well distributed. In the Salomé well field, the groundwater of wells $S 4 b$ and $S 8$ diverged from the mixing line with lower $\mathrm{Sr}$ values and lower $\mathrm{Sr}$ isotopic signatures that are closer to the isotopic signature of the Chalk aquifer of the Somme (Négrel and Petelet-Giraud, 2005) or La Bassée (Gourcy and Brenot, 2011). This isotopic variation can be explained by a contribution of slightly different groundwater closer to the local Chalk end-member solid leachates. According to the piezometric maps, the Salomé groundwater incorporates groundwater from the southwest and may also receive surface water from the Aire canal that could have a composition distinct from that of the Deûle River.

The ${ }^{87} \mathrm{Sr} /{ }^{86} \mathrm{Sr}$ vs. Mg/Sr diagram (Fig. 7) clearly represents the three groundwater components of the local ternary system defined in the previous $\mathrm{Ca} / \mathrm{Sr}$ vs. $\mathrm{Mg} / \mathrm{Sr}$ diagram of Figure 6with high $\mathrm{Mg} / \mathrm{Sr}$ ratios (200-600) and high ${ }^{87} \mathrm{Sr} /{ }^{86} \mathrm{Sr}$ values, especially for the Ypresian and Quaternary components. The groundwater of Well A12 near the local Se-rich end-member may typically result from a mixing between $T-Q$ leachates and confined groundwater as found at the confined pole of Well A26. This diagram also highlights the EH.A recharge pole with lower $\mathrm{Mg} / \mathrm{Sr}$ and higher ${ }^{87} \mathrm{Sr} /{ }^{86} \mathrm{Sr}$ values, which is clearly distinct from the A26-A12 mixing line. In the study site, however, the confined groundwater has high $\mathrm{Sr}$ and $\mathrm{Mg}$ concentrations, close to those of the Chalk rock, with a low $\mathrm{Mg} / \mathrm{Sr}$ ratio. Consequently, the $\mathrm{Mg}$ and $\mathrm{Sr}$ concentrations in the groundwater of the recharge and 
unconfined parts of the aquifer could potentially be controlled by $\mathrm{Mg}$ and $\mathrm{Sr}$ input from fertilizers.

In the clayey area in the northeast of the Les Ansereuilles, the difference in the ${ }^{87} \mathrm{Sr} /{ }^{86} \mathrm{Sr}$ ratios of wells $\mathrm{A} 12$ (0.70826), $\mathrm{A} 13$ (0.70811) and $\mathrm{A} 14$ (0.70806), which are $200 \mathrm{~m}$ apart, suggests (i) the contribution of a more radiogenic component through desorption of $\mathrm{Sr}$ from the upper radiogenic $T-Q$ end-member linked to the hydrological conditions, and (ii) a decreasing contribution of confined groundwater from wells A14 to A12. Given the geological context, the input of water from a different origin flowing along the Seclin Fault can also be expected and would have a greater impact on the groundwater of Well A14 (Fig. 2). However, if these fluxes had a chemical composition similar to the groundwater of Well $\mathrm{H} 11$, then they would bring a very low $\mathrm{Sr}$ content $(0.01 \mu \mathrm{mol} / \mathrm{L})$ with a strontium isotopic signature (0.70812) similar to that of Well A13 and would be of minor consequence. The wells in the central (A3-A4-A16) and southern (A17 to A24) parts of Les Ansereuilles displayed a lower variability than for the northern part and also a decreasing influence of the confined groundwaters of A26 type compensated by a higher contribution of the E-H.A end-member in coherence with the piezometric fluxes (Fig. 2).

Interestingly, data from the Upper Ypresian Cuisian aquifer in the Paris Basin (Brévilles catchment) displayed similar and higher $\mathrm{Sr}$ isotopic values and $\mathrm{Ca} / \mathrm{Sr}$ ratios (Brenot et al., 2008). The Cuisian groundwater also plots on the mixing line between Well A26 and the T-Q end-member. This relationship can be explained by the fact that the Cuisian aquifer is bound by the clayey Ypresian (Sparnacian), leaching of which could supply radiogenic Sr to the groundwater.

\subsection{Sr isotopes to constrain Se origins}

The significant variations of the $\mathrm{Sr}$ content and the ${ }^{87} \mathrm{Sr} /{ }^{86} \mathrm{Sr}$ ratio in groundwater during the monitoring year suggest various water-body pathways and mixings. The $\mathrm{Sr}$ isotopes were then used to better elucidate the Se origins.

The ${ }^{87} \mathrm{Sr} /{ }^{86} \mathrm{Sr}$ vs. Se/Sr diagram (Fig. 8) again reveals the three end-members of the ternary system: (1) The E-H.A groundwater, with the exception of Well $\mathrm{H} 4$ due to its higher Se content; (2) the A26-type confined groundwater which displayed an Se content of less than the quantification limit due to reductive conditions, but still represents an important endmember of the system; and (3), the A12 end-member completed with wells $\mathrm{H} 11$ and $\mathrm{H} 4$ representing the Se-rich groundwater in the depressed faulted area due to its high Se content and high Se/Sr ratio (0.045). 
The T-Q end-member displayed high ${ }^{87} \mathrm{Sr} /{ }^{86} \mathrm{Sr}$ and relatively high Se concentrations. More locally, the Se-rich end-member is related to the groundwater of wells $A 12, H 4$, and $\mathrm{H} 11$. The variations in the $\mathrm{Se} / \mathrm{Sr}$ ratio and in the $\mathrm{Sr}$ isotopic compositions in the neighboring wells $\mathrm{A} 12$, $A 13$ and $A 14$ can be explained by various mixings with groundwater of the A26 or A14 type and with various contributions of radiogenic $\mathrm{Sr}$ and $\mathrm{Se}$ from the upper clayey formation. Interestingly, the high Se contents in Well A13 in June and October (respectively 0.33 and $0.23 \mu \mathrm{mol} / \mathrm{L}$ ) corresponded to high and similar piezometric levels and were associated with the almost constant $\mathrm{Sr}$ concentrations (respectively 15.3 and $17.3 \mu \mathrm{mol} / \mathrm{L}$ ) and the $\mathrm{Sr}$ isotopic ratios that were exactly equal for the two dates $(0.7081)$. The A13 groundwater evolved along the mixing line between Wells $\mathrm{A} 14$ and A12 according to the different kinetics of the main processes affecting $\mathrm{Sr}$ and Se mobility, i.e. dissolution/precipitation and sorption.

The Houplin-Ancoisne wells showed distinct strontium isotopic ratios, but similar Se/Sr ratios (0.03) only slightly inferior to that of Well A12. Well H11 thus plots directly on a mixing line between the Well A26 and Well A12 end-members, confirming the influence of confined groundwater. Conversely, the composition of $\mathrm{H} 4$ can be explained by a mixing between groundwater from the E-H.A and the A12 end-members. As already discussed, this organization is supported by the presence of the main Seclin Fault which forms a hydraulic screen and provides high groundwater flows along preferential flow paths typically used for exploitation. This pattern is affected by the fact that Se is a redox reactive element that is immobile under reductive conditions and mobile under oxidizing conditions, and these are controlled by the confinement state of the Chalk aquifer and so can be linked to the $\mathrm{Mg}$ and $\mathrm{Sr}$ concentrations. Thus the very low Se/Sr ratios in the groundwater of wells A26 and A14 are explained by the low redox potential and the confinement conditions.

\subsection{Focus on Sr and Se mobility in wells A13 and H4: evidence of piezometric level influence}

The monitoring data have been completed with data acquired since 2000 . Only the chemical monitoring in wells $\mathrm{A} 13$ and $\mathrm{H} 4$, which showed significant variations, is given here.

Taking the case of Well A13 in Les Ansereuilles, it is worth noting that (1) the Se concentrations have exceeded the standard for drinking water $(0.12 \mu \mathrm{mol} / \mathrm{L})$ from 2005 to 2013, and (2) the static piezometric groundwater level has been located in the sediments overlying the Chalk (Fig. 9). The previous period of high piezometric levels corresponds to the rather famous 2001-2003 Somme floods (Négrel and Petelet-Giraud, 2005). The monitoring data showed that the variability of Se concentrations correlated well with 
variations in piezometric level and dissolved oxygen, except after 09/2012 when dissolved oxygen remained high (4-5 mg/L) while the Se content decreased; the high oxygen level could have been a consequence of the anomalous 2012 spring-summer recharge. The correlation between the Se content and the piezometric level is explained by the presence of Se in the clayey overlying formation (Cary et al., 2014). Furthermore, the presence of Se in the A11-A15 particular geological context is a second element that corroborates the hypothesis of a Tertiary age for the clayey formation in the WellA11-A15 area at 5-15 m depth (Fig 2). The strontium content showed slight variations opposed to those of Se $(-0.64)$ and the piezometric levels, with the lowest $\mathrm{Sr}$ values recorded during the anomalous period of high piezometric level in the summer (due to a very rainy spring and early summer). During this period of microporal saturation, oxygen and nitrates caused oxidation of the Sebearing phases present in the clayey deposits (Bailey et al., 2013; Bailey et al., 2012) and that the clays favored $\mathrm{Sr}$ adsorption. Conversely, during periods of lower piezometric level localized in the Chalk aquifer, the clayey formation was not leached by groundwater, thus inducing less Se mobilization and a higher Sr content in water.

The SF6 concentrations similarly showed a reverse correlation with the piezometric levels and the Se content (-0.73), except for the higher July value in Well A13. The highest SF6 contents were measured during winter where very low piezometric levels were recorded. These low piezometric levels can have triggered infiltration of recharge water, especially surface water from the Deûle River. The BMM correctly represented this evolution with a higher fraction of modern water in the winter and a mean $35 \%$ of modern water during the spring and summer seasons, except for the contaminated measurement in July 2012 (Fig. 9). The end-members identified with the isotopic strontium typology are again discriminated when plotting the percentage of modern water against the Se concentrations (Fig. 10). Because a time lag can be expected for the diffusive transport of SF6 through the unsaturated zone of a deep poorly porous aquifer, the apparent tracer age will be older than the true age of the recharge (Gooddy et al., 2006). The old water almost certainly originated from a mixing with old confined water of the A26 type and with leachates from the overlying clayey formation.

Taking the case of Well H4 in Houplin-Ancoisne, we again see an apparent increase of Se concentrations recorded from 2000 to 2013. Considering 2005-2013 data, the Se content close to the drinking water standard is clearly linked to the groundwater level rising above the Chalk formation. Here, the Se and $\mathrm{Sr}$ contents were well correlated $\left(\mathrm{R}^{2}=0.92\right)$ and the Se contents were negatively correlated with dissolved $\mathrm{O}_{2}\left(\mathrm{R}^{2}=-0.90\right)$. No clear correlation appeared between Se and the piezometric level nor with SF6, probably because the 
overlying deposits were constantly saturated. The Se content of the overlying clayey sediments is inferior to the one of the clays of Well A13 (Cary et al., in prep).

Finally, the drilling operation which requires daily stops and ignition of pumping impacts the variations of the dynamic level and thus alternating saturation or desaturation of the overlying clays. Strong and daily variations of the dynamic level of the water most surely contribute secondarily to mobilize the Se sources in the saturated zone. In order to limit Se contamination of the groundwater, the water operators have already decreased the pumping rates in the depressed area of wells A11-A15. A complete study of the spatial distribution of the Tertiary and Quaternary formations in the study area should enable new wells to be drilled away from them.

\section{Conclusions}

The specific geochemical signature of the Chalk groundwater south of Lille revealed by $\mathrm{Sr}$ isotopes, in addition to the major- and trace-element concentrations demonstrated a mixing of groundwater bodies where the main poles could be represented by: (1) the upstream groundwater in the recharge area with a higher ${ }^{87} \mathrm{Sr} /{ }^{86} \mathrm{Sr}$ ratio, probably controlled by fertilizer inputs, and SF6 contamination; (2) the confined groundwater with a high Sr concentration and the lowest ${ }^{87} \mathrm{Sr} /{ }^{86} \mathrm{Sr}, \mathrm{Ca} / \mathrm{Sr}$ and $\mathrm{Mg} / \mathrm{Sr}$ ratios of the study area, along with a higher contribution of pre-tracer water and a very low Se content; (3) the Se-rich groundwater. The four monitored wells tapping the Chalk aquifer showed strong temporal and spatial disparities as regards $\mathrm{Sr}$ and Se concentrations during a 21-month study.

The spatial and temporal disparities of the Se concentrations in this dynamic system can be explained by the geological and hydrogeological constraints, i.e. the presence of a Se-rich clayey formation identified as Tertiary overlying the Chalk aquifer, and variations of the piezometric level induced by natural recharge and pumping. Se mobility is enhanced by saturation and oxidation of the reductive clayey formation that locally confines the Chalk aquifer by SF6-contaminated groundwater. Strontium could, at the same time, be favorably adsorbed on clays. Pumping of the groundwater may also favor Se transfer towards piezometrically depleted areas.

In order to limit Se contamination in the groundwater, the geology of the study area should be revisited, so that new wells should be drilled in areas devoid of Se-rich clayey deposits, and connections with Se-rich wells should be as limited as possible. 
As a first approach, this multi-tool study successfully identified Se origins in the Chalk aquifer. There is now a need to explore Se-bearing phases in the Tertiary and Quaternary sediments and to better constraint the oxido-reductive conditions that control Se mobility and Se speciation, and especially the role of denitrification. This will help to a better exploitation of the groundwater resource.

\section{Acknowledgments}

This study was financed by the Lille urban community (LMCU), the French Geological Survey (BRGM), and the water operators Noréades and Eaux du Nord. The Research Direction of the BRGM is thanked for its additional support. The work benefited from the collaboration of C. Guerrot, C. Fléhoc and A.M. Gallas (BRGM Mass-Spectrometry team) who provided the $\mathrm{Sr}$ and $\mathrm{O}-\mathrm{H}$ isotopic analyses. It also benefited from the collaboration of $\mathrm{T}$. Conte (BRGM Chemistry laboratories) who provided the major- and trace-element analyses. Jean-Yves Caous is thanked for fruitful discussions. The water operators are thanked for their technical help in the field and for all the chemical records at our disposal. We are grateful to Patrick Skipwith for the English review. The authors are grateful to Kimberly Beisner and an anonymous reviewer for thoughtful revisions of the manuscript and constructive comments.

\section{References}

Bailey, R.T., Gates, T.K., Halvorson, A.D., 2013. Simulating variably-saturated reactive transport of selenium and nitrogen in agricultural groundwater systems. Journal of Contaminant Hydrology 149, 27-45.

Bailey, R.T., Hunter, W.J., Gates, T.K., 2012. The Influence of nitrate on selenium in irrigated agricultural groundwater systems. Journal of Environmental Quality 41, 783-792.

Bajaj, M., Eiche, E., Neumann, T., Winter, J., Gallert, C., 2011. Hazardous concentrations of selenium in soil and groundwater in North-West India. Journal of Hazardous Materials 189, 640-646.

Barron, E., Migeot, V., Seby, F., Ingrand, I., Potin-Gautier, M., Legube, B., Rabouan, S., 2012. Selenium exposure in subjects living in areas with high selenium concentrated drinking water: Results of a French integrated exposure assessment survey. Environ. Int. 40, 155161.

Beisner, K., Naftz, D.L., Johnson, W.P., Diaz, X., 2009. Selenium and trace element mobility affected by periodic displacement of stratification in the Great Salt Lake, Utah. Science of The Total Environment 407, 5263-5273. 
Bernard, D., Bosch, B., Caulier, P., 1981. Acquisition et rassemblement des données géothermiques disponibles et nouvelles dans la zone Franco-Belge de Saint-Ghislain à Saint-Amand-les-Eaux (Nord), in: BRGM/80-SGN-406-NPC (Ed.).

Blum, J.D., Erel, Y., Brown, K., 1994. 87Sr/86Sr ratios of Sierra Nevada stream waters: implications for relative mineral weathering rates. Geochimica et Cosmochimica Acta 58, 5019-5025.

Boulen, M., Salvador, P.-G., Deschodt, L., 2004. Formations sédimentaires et évolution de la vallée de la Deûle depuis le Pléniglaciaire supérieur à Houplin-Ancoisne (Nord de la France). Quaternaire, 269-284.

Bourg, A.C.M., Darmendrail, D., Ricour, J., 1989. Geochemical filtration of riverbank and migration of heavy-metals between the Deule River and the Ansereuilles alluvion-chalk aquifer (Nord, France). Geoderma 44, 229-244.

Brenot, A., Baran, N., Pételet-Giraud, E., Négrel, P., 2008. Interaction between different water bodies in a small catchment in the Paris basin (Brévilles, France): Tracing of multiple $\mathrm{Sr}$ sources through $\mathrm{Sr}$ isotopes coupled with $\mathrm{Mg} / \mathrm{Sr}$ and $\mathrm{Ca} / \mathrm{Sr}$ ratios. Applied Geochemistry 23, 58-75.

Caous, J.Y., 2003. Impact de l'activité industrielle sur la qualité de la nappe de la craie (champs captants du Sud de Lille - 59). Etat initial des connaissances géologiques et hydrogéologiques. Projet BRGM POLD05. BRGM, RP-52180-FR.

Cary, L., Benabderraziq, H., Elkhattabi, J., Parmentier, M., Gourcy, L., Négrel, P., 2014. Tracking selenium behaviour in chalk aquifer (northern France): $\mathrm{Sr}$ and 34S-sulphates isotopes constraints, EGU General Assembly 2014. Geophysical Research Abstracts 16, Wien (Austria).

Cary, L., Gourcy, L., Benabderraziq, H., Elkhattabi, J., Laurent, A., Négrel, P., 2013. Multi isotopic tools to understand selenium origins in groundwaters of the Chalk aquifer in Northern France, EGU General Assembly 2013. Geophysical Research Abstracts 15, Wien (Austria).

Chabart, M., Gourcy, L., Braibant, G., 2006. Origine des anomalies en sélénium dans les captages d'AEP du département de la Marne. Première approche, Rapport BRGM RP. 54939-FR.

Chuncai, Z., Guijian, L., Dun, W., Ting, F., Ruwei, W., Xiang, F., 2014. Mobility behavior and environmental implications of trace elements associated with coal gangue: A case study at the Huainan Coalfield in China. Chemosphere 95, 193-199.

Craig, H., 1961. Isotopic variations in meteoric waters. Science (New York, N.Y.) 133, 17021703.

Darling, W.G., Gooddy, D.C., MacDonald, A.M., Morris, B.L., 2012. The practicalities of using CFCs and SF6 for groundwater dating and tracing. Applied Geochemistry 27, 1688-1697.

Deverel, S.J., Gallanthine, S.K., 1989. Relation of salinity and selenium in shallow groundwater to hydrologic and geochemical processes, Western San Joaquin Valley, California. Journal of Hydrology 109, 125-149. 
Dhillon, K.S., Dhillon, S.K., 2003. Quality of underground water and its contribution towards selenium enrichment of the soil-plant system for seleniferous region of Northwest India. J. of Hydrology 272, 123-130.

Dogramaci, S.S., Herczeg, A.L., 2002. Strontium and carbon isotope constraints on carbonate-solution interactions and inter-aquifer mixing in groundwaters of the semi-arid Murray Basin, Australia. Journal of Hydrology 262, 50-67.

Drouet, T., Herbauts, J., Gruber, W., Demaiffe, D., 2005. Strontium isotope composition as a tracer of calcium sources in two forest ecosystems in Belgium. Geoderma 126, 203-223.

Edmunds, W.M., Cook, J.M., Darling, W.G., Kinniburgh, D.G., Miles, D.L., Bath, A.H., Morgan-Jones, M., Andrews, J.N., 1987. Baseline geochemical conditions in the Chalk aquifer, Berkshire, UK: a basis for groundwater quality management. Applied Geochemistry 2, 251-274.

Edmunds, W.M., Smedley, P.L., 2000. Residence time indicators in groundwater: the East Midlands Triassic sandstone aquifer. . Applied Geochemistry 15, 737-752.

Elliot, T., Andrews, J.N., Edmunds, W.M., 1999. Hydrochemical trends, palaeorecharge and groundwater ages in the fissured Chalk aquifer of the London and Berkshire Basins, UK. Applied Geochemistry 14, 333-363.

Faure, G., 1986. Principles of Isotope Geology. John Wiley and Sons. 589 p.

Garnier, J.M., 1976. Un modèle de l'estimation de l'activité initiale du carbone dissous et des vitesses d'écoulement en régime captif. PhD of UPMC.

Gat, J., 1981. Isotopic fractionation. In: Gat, J., Gonfiantini, R. (Eds), Stable isotope hydrology - Deuterium and Oxygen-18 in the water cycle. Technical Report Series N. 210, IAEA, Vienna.

Gates, T.K., Cody, B.M., Donnelly, J.P., Herting, A.W., Bailey, R.T., Price, J.M., 2009. Assessing selenium contamination in the irrigated stream-aquifer system of the Arkansas River, Colorado. Journal of Environmental Quality 38, 2344-2356.

Gooddy, D.C., Darling, W.G., Abesser, C., Lapworth, D.J., 2006. Using chlorofluorocarbons (CFCs) and sulphur hexafluoride (SF6) to characterise groundwater movement and residence time in a lowland Chalk catchment. Journal of Hydrology 330, 44-52.

Gourcy, L., Lions, J., Wyns, R., Dictor, M.C., Brenot, A., Crouzet, C., Ghestem, J.P., 2011. Origine du sélénium et compréhension des processus dans les eaux du bassin Seine-Normandie. Rapport final. BRGM/RP-59445-FR, 178 p.

Gourcy, L., Brenot, A., 2011. Multiple environmental tracers for a better understanding of water flux in a wetland area (La Bassée, France). Applied Geochemistry 26, 2147-2158.

Gourcy, L., Crastes de Paulet, F., 2012. Apport des outils chimiques et isotopiques dans la connaissance de l'aquifère du calcaire carbonifère. Rapport final. BRGM, RP-61124-FR.

Guan, D.M., Martin, J.-M., 1991. Selenium distribution in the Rhône delta and the Gulf of Lions. Marine Chemistry 36, 303-316. 
Huddard, P.A., Longstaffe, F.J., Crowe, A.S., 1999. dD and d180 evidence for inputs to groundwater at a wetland coastal boundary in the southern Great Lakes region of Canada. Journal of Hydrology 214, 18-31.

IAEA, 2006. Use of Chlorofluorocarbons in hydrology: A guidebook. STI/PUB 1238, IAEA, Vienna. 277p.

Kloppmann, W., Dever, L., Edmunds, W.M., 1996. Redox zones in the chalk aquifer of the Paris and North German basins. Hydrological Sciences Journal 41, 311-326.

Kulp, T.R., Pratt, L.M., 2004. Speciation and weathering of selenium in upper Cretaceous chalk and shale from South Dakota and Wyoming, USA. Geochim Cosmochim Ac 68, 36873701.

Liu, Y.T., Chen, T.Y., Mackebee, W.G., Ruhl, L., Vengosh, A., Hsu-Kim, H., 2013. Selenium Speciation in coal ash spilled at the Tennessee Valley Authority Kingston Site. Environ. Sci. Technol. 47, 14001-14009.

Masscheleyn, P.H., DeLaune, R.D., Patrick, W.H.J., 1990. Transformations of selenium as affected by sediment oxidation-reduction potential and $\mathrm{pH}$. Environ. Sci. Technol. 24, 91-96.

McArthur, J.M., Thirlwall, M.F., Gale, A.S., Kennedy, W.J., Burnett, J.A., Mattey, D., Lord, A.R., 1993. Strontium isotope stratigraphy for the Late Cretaceous: a new curve, based on the English Chalk, High Resolution Stratigraphy. From Hailwood, E.A. \& Kidd, R.B. (eds), pp. 195-209.

Meybeck, M., 1986. Composition chimique des ruisseaux non pollués de France. Sci. Géol. Bull. 39, 3-77.

Millot, R., Petelet-Giraud, E., Guerrot, C., Négrel, P., 2010. Multi-isotopic composition ( $\delta 7 \mathrm{Li}-$ $\delta 11 \mathrm{~B}-\delta \mathrm{D}-\delta 180$ ) of rainwaters in France: Origin and spatio-temporal characterization. Applied Geochemistry 25, 1510-1524.

Négrel, P., Casanova, J., Aranyossy, J.F., 2001. Strontium isotope systematics used to decipher the origin of groundwaters sampled from granitoids: the Vienne Case (France). Chemical Geology 177, 287-308.

Négrel, P., Petelet-Giraud, E., 2005. Strontium isotopes as tracers of groundwater-induced floods: the Somme case study (France). Journal of Hydrology 305, 99-119.

Oremland, R.S., Hollibaugh, J.T., Maest, A.S., Presser, T.S., Miller, L.G., Culbertson, C.W., 1989. Selenate reduction to elemental selenium by anaerobic bacteria in sediments and culture: biogeochemical significance of a novel, sulfate-independent respiration. Appl Environ Microbiol 55, 2333-2343.

Plummer, L.N., Busenberg, E., 1999. Chlorofluorocarbons, in: Cook, P.G., Herczeg, A.L. (Eds.), Environmental tracers in subsurface hydrology, Kluwer, Dordrecht, pp. 41-478.

Roy, S., Gaillardet, J., Allègre, C.J., 1999. Geochemistry of dissolved and suspended loads of the Seine river, France: Anthropogenic impact, carbonate and silicate weathering. Geochimica Et Cosmochimica Acta 63, 1277-1292. 
Simon, B., 1986. Apports de la biogéochimie isotopique à la connaissance de la dénitrification dans les eaux souterraines. Rapport 86-SGN-641 Université Pierre et Marie Curie, Paris VI.

Smedley, P.L., Edmunds, W.M., 2002. Redox patterns and trace-element behaviour in the East Midlands Triassic Sandstone Aquifer. U.K. Ground Water 40, 44-58.

Talbot, A., Philippart, S., Bailly, S., Caron, C., 1985. Champ captants de Ansereuilles, d'Emmerin et d'Houplin-Ancoisne. Modélisation des écoulements souterrains et des transferts de masse. Acquisition de données, in: 85-AGI-063-NPC, B. (Ed.).

Tuttle, M.L.W., Fahy, J.W., Elliott, J.G., Grauch, R.I., Stillings, L.L., Contaminants from cretaceous black shale: II. Effect of geology, weathering, climate, and land use on salinity and selenium cycling, Mancos Shale landscapes, southwestern United States. Applied Geochemistry, in press.

Vachier, P., Dever, L., Fontes, J.C., 1987. Mouvements de l'eau dans la zone non saturée et alimentation de la nappe de la craie de Champagne (France). IAEA STI-PUB-757 : 367-379.

Vengosh, A., Lindberg, T.T., Merola, B.R., Ruhl, L., Warner, N.R., White, A., Dwyer, G.S., Di Giulio, R.T., 2013. Isotopic imprints of mountaintop mining contaminants. Environ. Sci. Technol. 47, 10041-10048.

Vinceti, M., Crespi, C.M., Bonvicini, F., Malagoli, C., Ferrante, M., Marmiroli, S., Stranges, S., 2013. The need for a reassessment of the safe upper limit of selenium in drinking water. Science of The Total Environment 443, 633-642.

Vinceti, M., Maraldi, T., Bergomi, M., Malagoli, C., 2009. Risk of chronic low-dose selenium overexposure in humans: insights from epidemiology and biochemistry. Review. Rev Environ Health 24, 231-248.

Vitoria, L., Otero, N., Soler, A., Canals, A., 2004. Fertilizer characterization: Isotopic data (N, S, O, C, and Sr). Environ. Sci. Technol. 38, 3254-3262.

Widory, D., Kloppmann, W., Chery, L., Bonnin, J., Rochdi, H., Guinamant, J.-L., 2004. Nitrate in groundwater: an isotopic multi-tracer approach. Journal of Contaminant Hydrology 72 , 165-188.

Zawislanski, P.T., Mountford, H.S., Gabet, E.J., McGrath, A.E., Wong, H.C., 2001. Selenium distribution and fluxes in intertidal wetlands, San Francisco Bay, California. Journal of Environmental Quality 30, 1080-1091.

Zhang, Y.-C., Slomp, C.P., Broers, H.P., Bostick, B., Passier, H.F., Böttcher, M.E., Omoregie, E.O., Lloyd, J.R., Polya, D.A., Van Cappellen, P., 2012. Isotopic and microbiological signatures of pyrite-driven denitrification in a sandy aquifer. Chemical Geology 300-301, 123-132. 
Figure caption

Figure 1: Se content $(\mu \mathrm{g} / \mathrm{L})$ in groundwater (scale 1:1,000,000) affecting the southern and eastern parts of the Paris Basin due mainly to the Tertiary formations (data from the ADES database www.ades.eaufrance.fr).

Figure 2: Study site showing the geological formations, the four studied well fields and piezometric levels of the Chalk groundwater (geological scale 1:50,000), and the maxima of Se contents measured in the groundwater in 2011. Quaternary deposits cover the Tertiary formations (Louvil Clay, Ostricourt Sand, Flandres Clay) and the Cretaceous Chalk. The schematic A-B geological cross section is based on geological data (infoterre.brgm.fr) and provides new insights concerning the faulted depressed area (wells A11 to A15) the age of which could be Early Tertiary instead of Quaternary.

Figure 3: Stable ${ }^{2} \mathrm{H}$ and ${ }^{18} \mathrm{O}$ isotopes of the water molecule measured during the initial sampling and analysis program in June 2011, along with calculated 2012 summer and winter means of the Deûle River. Data from the Chalk aquifer, both regionally (Bernard et al., 1981; Simon, 1986; Vachier et al., 1987) and locally (Gourcy and Crastes de Paulet, 2012), plus local Carboniferous data, are also plotted.

Figure 4: Diagrams showing element concentrations in the groundwater and surface water of the study area, including results from the initial sampling and analysis and the monthly monitoring programs (the $\mathrm{Sr}$ vs. $\mathrm{Cl}$ and $\mathrm{Se}$ vs. $\mathrm{Cl}$ graphs both give all the monitoring values for wells $\mathrm{A} 13$ and $\mathrm{H} 4$ ). Data from ADES $\left(^{*}\right)$ are given in black crosses for confined groundwaters and grey crosses for A26 data when available.

Figure 5: a) Bedrock end-members: $\mathrm{Ca} / \mathrm{Sr}$ vs. $\mathrm{Mg} / \mathrm{Sr}(\mathrm{mol} / \mathrm{mol})$ in the solids sampled in the study region and at depth close to the wells. The Ypresian sample is from Montreuil-sur-Epte (Gourcy and Brenot, 2011) and the carbonates given by Meybeck (1986). b) Groundwater end-members: $\mathrm{Ca} / \mathrm{Sr}$ vs. $\mathrm{Mg} / \mathrm{Sr}(\mathrm{mol} / \mathrm{mol})$ in groundwater sampled from the study site. The groundwater data are from Gourcy and Crastes de Paulet (2012) for the Carboniferous and local Chalk groundwater, Négrel and Petelet (2005) for the Somme catchment Gourcy and Brenot (2011) for la Bassée, Brenot et al. (2008) for the Cuise Sand, Roy et al. (1999) for the Oise River, and Edmunds et al. (1987) for the Chalk aquifer in the London Basin. Errors are within the points. Mean values were calculated for the 2011, 2012 and 2013 samples.

Figure 6: $\mathrm{Ca} / \mathrm{Sr}(\mathrm{mol} / \mathrm{mol})$ vs. strontium isotopes in the sampled groundwater of the study area. Groundwater data from the bibliography were also plotted for the Chalk aquifer in Berkshire (London Basin (Edmunds et al., 1987), the Brévilles catchment (Brenot et al., 2008), La Bassée (Gourcy and Brenot, 2011) and the Somme catchment (Négrel and Petelet-Giraud, 2005). The strontium isotopic signature of local atmospheric inputs and Quaternary silt, together with the $\mathrm{Ca} / \mathrm{Sr}$ variation of atmospheric inputs, are from Drouet et al. (2005). The groundwater plots on a mixing line between two poles in the Chalk aquifer and were inscribed in a regional ternary system defined by the silicate and carbonate poles, the latter evolving between free and confined conditions that imply varying degrees of water-rock interaction. 
Figure 7: $\mathrm{Mg} / \mathrm{Sr}(\mathrm{mol} / \mathrm{mol})$ vs. strontium isotopes in the sampled groundwater of the study site. The regional system is defined by a very radiogenic silicate end-member and by the low isotopic composition of the solid Chalk. The diagram shows three poles of mixing that better define the $\mathrm{Sr}$ isotopic composition of the Chalk aquifer groundwater: (1) the Emmerin (E-H.A) end-member pole, (2) the A26 confined pole, and (3) the A12 end-member pole that is clearly different from the other Chalk poles. Data for the Somme catchment (Négrel and Petelet-Giraud, 2005), the Cuise Sand in the Brévilles catchment (Brenot et al., 2008), and the Chalk aquifer in the London Basin (Edmunds et al., 1987) are indicated. Errors are within the points.

Figure 8: $\mathrm{Se} / \mathrm{Sr}(\mathrm{mol} / \mathrm{mol})$ vs. strontium isotopes in the sampled groundwater of the study site. This diagram shows the local Se-rich end-member of Well A12 and the chemical relationships with the groundwater of wells $\mathrm{H} 11$ and $\mathrm{H} 4$. The three poles of the Chalk aquifer are still well defined. Errors are within the points.

Figure 9: Evolution of the selenium, strontium, dissolved oxygen and SF6 concentrations in the groundwater of a) Les Ansereuilles Well A13, and b) Houplin-Ancoisne Well H4, along with pumping rates and piezometric levels versus time. Chemical data prior to 2011 as well as the pumping rates and piezometric levels are from the water operators.

Figure 10: Percentage of young waters vs. Se content in the studied groundwaters. For monitoring in well $A 13$, months are indicated. The end-members identified with the isotopic strontium typology are again well discriminated. 


\section{Supporting Information}

Table 1: Physical and chemical analyses of the surface water and groundwater from the study area. Deûle data are for the Deûle River, and among groundwater, all samples names of wells with $\mathrm{A}$ are for Les Ansereuilles, with $\mathrm{E}$ for Emmerin, with $\mathrm{H}$ for Houplin-Ancoisne and $S$ for Salomé. 


\begin{tabular}{|c|c|c|c|c|c|c|c|c|c|c|c|c|c|c|c|c|c|c|c|}
\hline Sample & date & $\mathrm{T}^{\circ} \mathrm{C}$ & $\mathrm{pH}$ & ${ }^{87} \mathrm{Sr} /{ }^{86} \mathrm{Sr}$ & $\begin{array}{c}\delta^{18} \mathrm{O} \\
\text { vs. } \\
\text { SMOW } \\
, \% o \\
\end{array}$ & $\begin{array}{c}\delta^{2} \mathrm{H} \text { vs. } \\
\text { SMOW, } \\
\% \text {, }\end{array}$ & $\begin{array}{l}\text { TDS } \\
\mathrm{mg} / \mathrm{L}\end{array}$ & $\begin{array}{c}\mathrm{Ca} \\
\mathrm{mmol} / \mathrm{L}\end{array}$ & $\underset{\mathrm{mmol} / \mathrm{L}}{\mathrm{Mg}}$ & $\underset{\mathrm{Na}}{\mathrm{Nmol} / \mathrm{L}}$ & $\begin{array}{c}\mathrm{K} \\
\mathrm{mmol} / \mathrm{L}\end{array}$ & $\begin{array}{l}\mathrm{HCO}_{3} \\
\mathrm{mmo} / / \mathrm{L}\end{array}$ & $\begin{array}{c}\mathrm{Cl} \\
\mathrm{mmol} / \mathrm{L}\end{array}$ & $\underset{\mu \mathrm{mol} / \mathrm{L}}{\mathrm{Sr}}$ & $\underset{\mu \mathrm{mol} / \mathrm{L}}{\mathrm{Se}}$ & $\underset{\%}{\mathrm{NCIB}}$ & $\begin{array}{c}\text { SI } \\
\text { Calcite }\end{array}$ & $\begin{array}{c}\text { SI } \\
\text { Dolomite }\end{array}$ & $\begin{array}{c}\text { SF6 } \\
\mathrm{fmol} / \mathrm{L}\end{array}$ \\
\hline A12 & $15 / 06 / 11$ & 11.9 & 6.84 & 0.70825 & -6.8 & -46.8 & 1066 & 5.31 & 0.93 & 1.52 & 0.36 & 7.13 & 1.71 & 8.39 & 0.384 & $1 \%$ & 0.06 & -0.7 & 0.9 \\
\hline $\mathrm{A} 13$ & $07 / 02 / 12$ & 9.4 & 6.88 & & -5.87 & -45.55 & 1118 & 5.28 & 1.12 & 1.67 & 0.31 & 8.13 & 1.62 & 16.90 & 0.195 & $0 \%$ & 0.1 & -0.57 & 1.7 \\
\hline A13 & $08 / 03 / 12$ & 11.4 & 7 & & -6.02 & -45.55 & 1116 & 5.44 & 1.17 & 1.72 & 0.31 & 7.95 & 1.66 & 16.16 & 0.223 & $2 \%$ & 0.26 & -0.21 & 1.2 \\
\hline A13 & $02 / 04 / 12$ & 12 & 7.05 & & -6.78 & -46.56 & 1124 & 5.02 & 1.10 & 1.58 & 0.29 & 8.11 & 1.78 & 17.88 & 0.304 & $-4 \%$ & 0.3 & -0.12 & 1.1 \\
\hline $\mathrm{A} 13$ & $02 / 05 / 12$ & 12 & 7.18 & & -6.81 & -46.86 & 1062 & 4.95 & 0.98 & 1.53 & 0.33 & 7.59 & 1.66 & 12.30 & 0.320 & $-2 \%$ & 0.4 & 0.04 & 0.9 \\
\hline A13 & $11 / 06 / 12$ & 12.4 & 7.09 & 0.70811 & -6.81 & -46.11 & 1114 & 5.24 & 1.10 & 1.58 & 0.30 & 8.21 & 1.58 & 15.32 & 0.333 & $1 \%$ & 0.37 & 0.01 & 1 \\
\hline A13 & $03 / 07 / 12$ & 13 & 7.24 & & -6.76 & -46.30 & 1081 & 5.11 & 1.01 & 1.59 & 0.31 & 7.80 & 1.63 & 14.02 & 0.4 & $-1 \%$ & 0.5 & 0.26 & 1.4 \\
\hline A13 & $30 / 07 / 12$ & 12.4 & 7.29 & & -6.75 & -46.32 & 1076 & 5.14 & 0.96 & 1.58 & 0.33 & 7.64 & 1.55 & 11.56 & 0.390 & $-1 \%$ & 0.53 & 0.29 & 1 \\
\hline A13 & $06 / 09 / 12$ & 12.6 & 6.84 & & -6.78 & -46.20 & 1073 & 5.05 & 1.07 & 1.50 & 0.29 & 7.59 & 1.61 & 14.35 & 0.319 & $-1 \%$ & 0.08 & -0.57 & 1.1 \\
\hline $\mathrm{A} 13$ & $02 / 10 / 12$ & 12.3 & 6.9 & 0.70811 & -6.81 & -46.20 & 1127 & 5.36 & 1.12 & 1.58 & 0.31 & 8.11 & 1.69 & 17.29 & 0.230 & $1 \%$ & 0.18 & -0.37 & - \\
\hline A13 & $06 / 11 / 12$ & 11.7 & 6.89 & & -6.80 & -46.00 & 1109 & 5.47 & 1.08 & 1.44 & 0.28 & 8.13 & 1.91 & 15.35 & 0.186 & $0 \%$ & 0.17 & -0.42 & 1.1 \\
\hline A13 & $04 / 12 / 12$ & 11.4 & 6.98 & & -6.80 & -46.40 & 1127 & 5.33 & 1.09 & 1.60 & 0.27 & 8.26 & 1.65 & 16.66 & 0.175 & $1 \%$ & 0.25 & -0.26 & 1.3 \\
\hline A13 & $08 / 01 / 13$ & 11.7 & 6.95 & & -6.80 & -46.20 & 1146 & 5.30 & 1.09 & 1.65 & 0.29 & 8.06 & 1.81 & 15.02 & 0.162 & $-2 \%$ & 0.21 & -0.33 & 1.5 \\
\hline A13 & $05 / 02 / 13$ & 11.2 & 6.93 & & -6.8 & -46.1 & 1087 & 5.42 & 1.15 & 1.73 & 0.30 & 8.06 & 1.47 & 16.90 & 0.179 & $4 \%$ & 0.2 & -0.35 & - \\
\hline $\mathrm{A} 13$ & $05 / 03 / 13$ & 12.1 & 6.93 & & -6.80 & -46.70 & 1112 & 5.48 & 1.07 & 1.65 & 0.29 & 8.13 & 1.57 & 13.71 & 0.185 & $2 \%$ & 0.22 & -0.33 & - \\
\hline A14 & $15 / 06 / 11$ & 12.1 & 6.78 & 0.708062 & -6.7 & -46.4 & 1104 & 5.11 & 1.05 & 2.07 & 0.24 & 7.78 & 2.00 & 19.52 & $<\mathrm{LQ}$ & $1 \%$ & 0.02 & -0.7 & 0.7 \\
\hline A17 & $15 / 06 / 11$ & 12.5 & 6.79 & 0.708197 & -6.7 & -46.6 & 1053 & 5.02 & 0.86 & 1.89 & 0.25 & 7.74 & 1.62 & 8.61 & 0.108 & $1 \%$ & 0.04 & -0.74 & 1.4 \\
\hline A18 & $15 / 06 / 11$ & 12.2 & 6.88 & 0.708133 & -6.6 & -46.0 & 914 & 4.27 & 0.72 & 1.89 & 0.18 & 7.16 & 1.70 & 9.55 & 0.092 & $1 \%$ & 0.04 & -0.75 & 1.8 \\
\hline A23 & $15 / 06 / 11$ & 12.3 & 6.85 & 0.708106 & -6.2 & -44.2 & 935 & 4.54 & 0.65 & 1.97 & 0.15 & 6.90 & 1.85 & 7.16 & 0.138 & $2 \%$ & 0.01 & -0.86 & 2.5 \\
\hline A24 & $15 / 06 / 11$ & 11.8 & 6.88 & 0.708246 & -6.5 & -45.6 & 921 & 4.19 & 0.59 & 2.36 & 0.11 & 7.18 & 1.93 & 7.89 & 0.022 & $0 \%$ & 0.02 & -0.86 & 1.36 \\
\hline A24 & $07 / 02 / 12$ & 9.5 & 7.08 & - & -5.64 & -44.74 & 908 & 4.24 & 0.63 & 1.93 & 0.15 & 6.92 & 1.75 & 7.42 & 0.151 & $0 \%$ & 0.17 & -0.59 & 2.2 \\
\hline A24 & $08 / 03 / 12$ & 11.5 & 7.11 & - & -5.77 & -44.43 & 901 & 4.26 & 0.63 & 1.99 & 0.14 & 6.80 & 1.76 & 7.14 & 0.148 & $1 \%$ & 0.23 & -0.43 & 2.2 \\
\hline A24 & $02 / 04 / 12$ & 12.2 & 7.15 & - & -6.57 & -45.67 & 824 & 4.11 & 0.63 & 1.85 & 0.15 & 5.44 & 1.88 & 8.03 & 0.182 & $4 \%$ & 0.18 & -0.51 & 2.2 \\
\hline A24 & $02 / 05 / 12$ & 11.9 & 7.23 & - & -6.63 & -45.95 & 908 & 4.15 & 0.62 & 1.86 & 0.15 & 6.85 & 1.76 & 7.13 & 0.144 & $-2 \%$ & 0.35 & -0.18 & 1.5 \\
\hline A24 & $11 / 06 / 12$ & 12.3 & 7.3 & - & -6.60 & -45.59 & 908 & 4.22 & 0.65 & 1.79 & 0.15 & 6.98 & 1.67 & 7.34 & 0.128 & $1 \%$ & 0.44 & 0.02 & 2.5 \\
\hline A24 & $03 / 07 / 12$ & 13.1 & 7.28 & - & -6.62 & -46.63 & 929 & 4.39 & 0.65 & 1.90 & 0.15 & 6.95 & 1.75 & 7.74 & 0.177 & $0 \%$ & 0.45 & 0.03 & 2.1 \\
\hline A24 & $30 / 07 / 12$ & 13 & 7.23 & - & -6.65 & -45.80 & 932 & 4.42 & 0.63 & 1.87 & 0.16 & 6.92 & 1.68 & 7.28 & 0.156 & $0 \%$ & 0.4 & -0.09 & 1.7 \\
\hline A24 & $06 / 09 / 12$ & 12.7 & 6.97 & - & -6.65 & -45.80 & 904 & 4.14 & 0.64 & 1.82 & 0.15 & 6.88 & 1.73 & 7.54 & 0.151 & $-2 \%$ & 0.11 & -0.64 & 1.7 \\
\hline A24 & $02 / 10 / 12$ & 12.2 & 7.02 & - & -6.63 & -45.80 & 911 & 4.29 & 0.63 & 1.89 & 0.16 & 6.88 & 1.71 & 7.26 & 0.163 & $0 \%$ & 0.16 & -0.56 & - \\
\hline A24 & $06 / 11 / 12$ & 11.7 & 6.99 & - & -6.60 & -45.80 & 934 & 4.28 & 0.62 & 2.10 & 0.14 & 6.91 & 1.95 & 8.58 & 0.144 & $-1 \%$ & 0.12 & -0.66 & 1.8 \\
\hline
\end{tabular}




\begin{tabular}{|c|c|c|c|c|c|c|c|c|c|c|c|c|c|c|c|c|c|c|c|}
\hline A24 & $04 / 12 / 12$ & 11.7 & 7.05 & - & -6.60 & -45.70 & 922 & 4.28 & 0.65 & 1.88 & 0.14 & 7.01 & 1.70 & 7.51 & 0.152 & $1 \%$ & 0.19 & -0.5 & 2 \\
\hline A24 & $08 / 01 / 13$ & 11 & 7.09 & - & -6.60 & -45.90 & 943 & 4.40 & 0.65 & 1.92 & 0.15 & 6.85 & 1.84 & 6.78 & 0.175 & $-1 \%$ & 0.22 & -0.48 & 2.6 \\
\hline A24 & $05 / 02 / 13$ & 10.7 & 7.07 & - & -6.6 & -45.7 & 898 & 4.44 & 0.67 & 1.95 & 0.16 & 6.85 & 1.49 & 8.09 & 0.195 & $4 \%$ & 0.2 & -0.5 & - \\
\hline A24 & $05 / 03 / 13$ & 12.1 & 7.03 & - & -6.60 & -46.00 & 917 & 4.44 & 0.64 & 1.84 & 0.16 & 6.87 & 1.61 & 7.35 & 0.161 & $1 \%$ & 0.18 & -0.53 & - \\
\hline A26 & $15 / 06 / 11$ & 12 & 6.99 & 0.707887 & -6.5 & -45.6 & 999 & 2.82 & 1.60 & 3.28 & 0.49 & 7.95 & 1.79 & 54.78 & $<\mathrm{LQ}$ & $1 \%$ & 0 & -0.29 & 0.2 \\
\hline A3 & $15 / 06 / 11$ & 12 & 6.85 & $0.708217-$ & -6.8 & -47.2 & 894 & 4.44 & 0.72 & 1.41 & 0.22 & 6.51 & 1.55 & 7.99 & 0.184 & $1 \%$ & -0.02 & -0.89 & 0.9 \\
\hline A4 & $15 / 06 / 11$ & 12.6 & 6.75 & 0.708175 & -6.4 & -45.0 & 1073 & 4.92 & 1.03 & 2.15 & 0.17 & 8.05 & 1.71 & 12.21 & 0.020 & $1 \%$ & 0 & -0.72 & 0.9 \\
\hline E10 & $16 / 06 / 11$ & 12 & 6.9 & 0.708457 & -6.49 & -45.6 & 926 & 5.06 & 0.31 & 1.50 & 0.19 & 6.06 & 1.85 & 4.83 & 0.044 & $2 \%$ & 0.05 & -1.17 & 2.4 \\
\hline E5 & $16 / 06 / 11$ & 11.7 & 6.92 & 0.708408 & -6.49 & -45.6 & 860 & 4.67 & 0.25 & 1.40 & 0.21 & 5.42 & 1.78 & 4.74 & 0.023 & $1 \%$ & -0.01 & -1.35 & 1.7 \\
\hline $\mathrm{E} 7$ & $16 / 06 / 11$ & 11.2 & 6.92 & 0.708403 & -6.49 & -45.6 & 918 & 4.94 & 0.33 & 1.47 & 0.20 & 5.90 & 1.88 & 4.91 & 0.049 & $1 \%$ & 0.04 & -1.18 & 1.7 \\
\hline $\mathrm{H} 11$ & $16 / 06 / 11$ & 11.7 & 6.84 & 0.708119 & -6.87 & -47.1 & 1003 & 5.02 & 0.90 & 1.35 & 0.22 & 7.51 & 1.71 & 10.25 & 0.322 & $1 \%$ & 0.06 & -0.68 & 1.5 \\
\hline $\mathrm{H} 4$ & $16 / 06 / 11$ & 12.1 & 6.9 & 0.708374 & -6.48 & -45.1 & 889 & 4.52 & 0.36 & 1.83 & 0.20 & 6.13 & 1.93 & 4.70 & 0.153 & $0 \%$ & 0.01 & -1.13 & 2.4 \\
\hline $\mathrm{H} 4$ & $07 / 02 / 12$ & 10 & 7 & - & -5.81 & -45.19 & 955 & 4.93 & 0.47 & 1.64 & 0.20 & 6.65 & 1.70 & 6.12 & 0.172 & $1 \%$ & 0.14 & -0.83 & 3.3 \\
\hline $\mathrm{H} 4$ & $08 / 03 / 12$ & 11.7 & 7.13 & - & -5.91 & -45.34 & 936 & 4.83 & 0.46 & 1.60 & 0.19 & 6.47 & 1.68 & 5.99 & 0.180 & $0 \%$ & 0.28 & -0.52 & 2.3 \\
\hline $\mathrm{H} 4$ & $02 / 04 / 12$ & 13.4 & 7.1 & - & -6.78 & -46.78 & 939 & 4.71 & 0.47 & 1.55 & 0.21 & 6.51 & 1.77 & 6.04 & 0.168 & $-1 \%$ & 0.27 & -0.49 & 2.1 \\
\hline $\mathrm{H} 4$ & $02 / 05 / 12$ & 11.8 & 7.2 & - & -6.83 & -47.12 & 895 & 4.36 & 0.41 & 1.45 & 0.19 & 6.29 & 1.69 & 5.35 & 0.112 & $-3 \%$ & 0.31 & -0.48 & 1.8 \\
\hline $\mathrm{H} 4$ & $11 / 06 / 12$ & 12.8 & 7.27 & - & -6.91 & -47.22 & 871 & 4.35 & 0.39 & 1.43 & 0.20 & 6.24 & 1.59 & 6.03 & 0.098 & $-1 \%$ & 0.39 & -0.3 & 2.6 \\
\hline $\mathrm{H} 4$ & $03 / 07 / 12$ & 14 & 7.3 & - & -6.91 & -47.67 & 873 & 4.45 & 0.39 & 1.48 & 0.20 & 6.13 & 1.67 & 5.62 & 0.100 & $0 \%$ & 0.44 & -0.2 & 2 \\
\hline $\mathrm{H} 4$ & $30 / 07 / 12$ & 13.4 & 7.37 & - & -6.99 & -47.90 & 849 & 4.35 & 0.34 & 1.40 & 0.19 & 5.93 & 1.59 & 4.95 & 0.068 & $0 \%$ & 0.48 & -0.17 & 1.7 \\
\hline $\mathrm{H} 4$ & $06 / 09 / 12$ & 13.9 & 7.02 & - & -6.93 & -47.60 & 850 & 4.23 & 0.37 & 1.42 & 0.19 & 6.03 & 1.67 & 5.17 & 0.073 & $-1 \%$ & 0.14 & -0.8 & 2.4 \\
\hline $\mathrm{H} 4$ & $02 / 10 / 12$ & 12.8 & 7.03 & - & -6.90 & -47.20 & 870 & 4.36 & 0.40 & 1.48 & 0.21 & 6.08 & 1.70 & 5.42 & 0.081 & $1 \%$ & 0.14 & -0.79 & - \\
\hline $\mathrm{H} 4$ & $06 / 11 / 12$ & 11.5 & 7.02 & - & -6.90 & -46.90 & 882 & 4.50 & 0.41 & 1.44 & 0.19 & 6.23 & 1.73 & 6.64 & 0.093 & $0 \%$ & 0.13 & -0.84 & 1.7 \\
\hline $\mathrm{H} 4$ & $04 / 12 / 12$ & 11.1 & 7.15 & - & -7.00 & -46.90 & 897 & 4.52 & 0.42 & 1.47 & 0.19 & 6.26 & 1.72 & 5.67 & 0.119 & $-1 \%$ & 0.26 & -0.59 & 2.2 \\
\hline $\mathrm{H} 4$ & $08 / 01 / 13$ & 11 & 7.13 & - & -6.90 & -46.70 & 903 & 4.49 & 0.40 & 1.46 & 0.21 & 6.08 & 1.87 & 5.66 & 0.095 & $-2 \%$ & 0.22 & -0.68 & 2.6 \\
\hline $\mathrm{H} 4$ & $05 / 02 / 13$ & 10.2 & 7.12 & - & -6.9 & -46.9 & 847 & 4.58 & 0.42 & 1.48 & 0.21 & 6.03 & 1.52 & 6.15 & 0.068 & $4 \%$ & 0.2 & -0.72 & - \\
\hline $\mathrm{H} 4$ & $05 / 03 / 13$ & 12.2 & 7.07 & & -6.90 & -46.70 & 860 & 4.57 & 0.40 & 1.42 & 0.20 & 6.08 & 1.57 & 4.99 & 0.065 & $3 \%$ & 0.19 & -0.73 & - \\
\hline $\mathrm{H} 6$ & $16 / 06 / 11$ & 11.7 & 6.9 & 0.708307 & -6.9 & -47.3 & 916 & 4.92 & 0.39 & 1.33 & 0.17 & 6.15 & 1.73 & 5.33 & 0.082 & $1 \%$ & 0.04 & -1.09 & 2.3 \\
\hline $\mathrm{H} 9$ & $16 / 06 / 11$ & 11.9 & 6.92 & 0.708365 & -6.8 & -47.1 & 880 & 4.34 & 0.37 & 1.61 & 0.21 & 5.98 & 1.95 & 4.77 & 0.061 & $-1 \%$ & 0.01 & -1.11 & 2.6 \\
\hline $\mathrm{S} 11$ & $17 / 06 / 11$ & 12.2 & 6.82 & 0.708096 & -6.5 & -45.2 & 1125 & 5.04 & 0.87 & 2.64 & 0.31 & 7.28 & 1.92 & 13.01 & 0.020 & $0 \%$ & 0.03 & -0.76 & 1.9 \\
\hline S3 & $14 / 06 / 11$ & 12 & 6.91 & 0.708057 & -6.7 & -46.2 & 906 & 4.39 & 0.77 & 1.60 & 0.23 & 6.69 & 1.65 & 13.81 & 0.088 & $1 \%$ & 0.04 & -0.73 & 1.7 \\
\hline S3 & $07 / 02 / 12$ & 9.2 & 7.05 & - & -5.70 & -44.63 & 969 & 4.48 & 0.79 & 1.99 & 0.23 & 7.06 & 1.67 & 15.44 & 0.046 & $0 \%$ & 0.16 & -0.54 & 3.1 \\
\hline S3 & $08 / 03 / 12$ & 12 & 7.08 & - & -5.82 & -45.31 & 944 & 4.41 & 0.79 & 1.90 & 0.21 & 6.87 & 1.66 & 14.03 & 0.081 & $0 \%$ & 0.22 & -0.36 & 2.7 \\
\hline S3 & $02 / 04 / 12$ & 13.2 & 7.16 & - & -6.61 & -45.66 & 977 & 4.25 & 0.80 & 1.84 & 0.23 & 7.03 & 1.81 & 16.72 & 0.075 & $-4 \%$ & 0.31 & -0.13 & 2.1 \\
\hline
\end{tabular}




\begin{tabular}{|c|c|c|c|c|c|c|c|c|c|c|c|c|c|c|c|c|c|c|c|}
\hline S3 & $02 / 05 / 12$ & 11.9 & 7.22 & - & -6.65 & -45.73 & 960 & 4.37 & 0.81 & 1.85 & 0.24 & 6.90 & 1.72 & 14.33 & 0.074 & $-2 \%$ & 0.36 & -0.08 & 1.9 \\
\hline S3 & $11 / 06 / 12$ & 12.4 & 7.26 & - & -6.66 & -45.72 & 980 & 4.45 & 0.82 & 1.96 & 0.25 & 7.09 & 1.62 & 13.34 & 0.047 & $1 \%$ & 0.42 & 0.06 & 2.5 \\
\hline S3 & $03 / 07 / 12$ & 14.1 & 7.3 & - & -6.65 & -45.98 & 982 & 4.52 & 0.85 & 1.99 & 0.25 & 7.00 & 1.71 & 16.06 & 0.068 & $0 \%$ & 0.49 & 0.24 & \\
\hline S3 & $30 / 07 / 12$ & 13.2 & 7.32 & - & -6.65 & -45.00 & 1008 & 4.51 & 0.83 & 1.99 & 0.25 & 6.98 & 1.75 & 14.27 & 0.062 & $-3 \%$ & 0.49 & 0.21 & 1.8 \\
\hline S3 & 06/09/12 & 12.4 & 7.01 & - & -6.62 & -45.60 & 986 & 4.37 & 0.85 & 2.02 & 0.25 & 7.00 & 1.77 & 14.15 & 0.059 & $-2 \%$ & 0.16 & -0.44 & 2.1 \\
\hline S3 & $02 / 10 / 12$ & 12.4 & 7.07 & - & -6.65 & -45.80 & 999 & 4.42 & 0.87 & 2.24 & 0.29 & 7.08 & 1.75 & 15.60 & 0.037 & $1 \%$ & 0.23 & -0.3 & - \\
\hline S3 & $06 / 11 / 12$ & 11.7 & 7.07 & - & -6.60 & -45.60 & 980 & 4.60 & 0.84 & 1.59 & 0.24 & 7.08 & 1.83 & 15.14 & 0.051 & $-2 \%$ & 0.23 & -0.33 & 2.7 \\
\hline S3 & $04 / 12 / 12$ & 11.1 & 7.08 & - & -6.70 & -45.30 & 1004 & 4.57 & 0.86 & 2.06 & 0.24 & 7.10 & 1.75 & 14.91 & 0.078 & $1 \%$ & 0.23 & -0.34 & 2.5 \\
\hline S3 & $08 / 01 / 13$ & 11.2 & 7.1 & - & -6.50 & -44.30 & 991 & 4.53 & 0.84 & 1.72 & 0.24 & 6.77 & 1.85 & 14.72 & 0.117 & $-3 \%$ & 0.23 & -0.34 & 4.7 \\
\hline S3 & $05 / 02 / 13$ & 10.7 & 7.1 & - & -6.5 & -44.3 & 960 & 4.71 & 0.91 & 1.92 & 0.26 & 6.87 & 1.54 & 16.71 & 0.079 & $4 \%$ & 0.24 & -0.31 & - \\
\hline S3 & $05 / 03 / 13$ & 12.1 & 7.1 & - & -6.50 & -44.20 & 968 & 4.67 & 0.87 & 1.76 & 0.25 & 6.87 & 1.62 & 14.12 & 0.087 & $2 \%$ & 0.26 & -0.26 & - \\
\hline S4b & $14 / 06 / 11$ & 12.1 & 6.9 & 0.708041 & -6.8 & -46.8 & 848 & 4.52 & 0.37 & 1.42 & 0.14 & 6.69 & 1.37 & 6.89 & 0.018 & $2 \%$ & 0.06 & -1.03 & 1.9 \\
\hline S8 & $17 / 06 / 11$ & 12 & 6.89 & 0.708082 & -6.7 & -45.9 & 861 & 4.59 & 0.43 & 1.34 & 0.13 & 6.41 & 1.71 & 7.00 & 0.120 & $2 \%$ & 0.03 & -1.02 & 3.6 \\
\hline Deûle & $07 / 02 / 12$ & 1.3 & 8 & - & -5.79 & -44.98 & 766 & 3.20 & 0.46 & 2.35 & 0.28 & 5.65 & 2.05 & 5.34 & 0.022 & $0 \%$ & 0.76 & 0.4 & \\
\hline Deûle & $08 / 03 / 12$ & 8 & 7.89 & - & -7.76 & -59.39 & 583 & 2.52 & 0.33 & 1.85 & 0.20 & 4.11 & 1.71 & 3.97 & 0.027 & $1 \%$ & 0.55 & 0.09 & \\
\hline Deûle & $02 / 04 / 12$ & 14.1 & 8.39 & - & -6.80 & -46.91 & 769 & 3.27 & 0.48 & 2.33 & 0.27 & 5.67 & 2.10 & 5.51 & 0.026 & $-1 \%$ & 1.38 & 1.91 & \\
\hline Deûle & $02 / 05 / 12$ & 13.5 & 8.3 & - & -6.70 & -46.52 & 646 & 2.80 & 0.39 & 1.97 & 0.23 & 4.75 & 1.79 & 4.87 & 0.017 & $1 \%$ & 1.16 & 1.42 & \\
\hline Deûle & $11 / 06 / 12$ & 17.6 & 8.11 & - & -6.27 & -43.60 & 700 & 2.99 & 0.42 & 2.08 & 0.23 & 5.37 & 1.79 & 4.85 & 0.021 & $-1 \%$ & 1.11 & 1.4 & \\
\hline Deûle & $03 / 07 / 12$ & 21.6 & 8.25 & - & -6.17 & -43.55 & 621 & 2.72 & 0.36 & 1.93 & 0.23 & 4.88 & 1.71 & 4.61 & 0.019 & $0 \%$ & 1.24 & 1.7 & \\
\hline Deûle & $30 / 07 / 12$ & 22 & 8.19 & - & -6.36 & -44.81 & 659 & 2.84 & 0.38 & 2.07 & 0.24 & 4.92 & 1.77 & 4.55 & 0.018 & $0 \%$ & 1.21 & 1.64 & \\
\hline Deûle & $06 / 09 / 12$ & 21.2 & 8.32 & - & -6.20 & -44.30 & 689 & 2.85 & 0.42 & 2.30 & 0.25 & 5.26 & 1.99 & 5.00 & 0.018 & $-1 \%$ & 1.35 & 1.95 & \\
\hline Deûle & $06 / 11 / 12$ & 9.85 & 7.88 & - & -6.60 & -43.80 & 671 & 2.79 & 0.37 & 1.83 & 0.21 & 5.01 & 1.86 & 5.08 & 0.017 & $-4 \%$ & 0.7 & 0.42 & \\
\hline Deûle & $04 / 12 / 12$ & 7 & 7.96 & - & -6.90 & -46.40 & 721 & 3.15 & 0.41 & 1.90 & 0.20 & 5.69 & 1.73 & 5.00 & 0.014 & $1 \%$ & 0.83 & 0.62 & \\
\hline Deûle & $08 / 01 / 13$ & 8.4 & 7.89 & - & -6.80 & -45.60 & 741 & 3.19 & 0.45 & 1.78 & 0.20 & 5.41 & 1.76 & 5.64 & 0.021 & $-3 \%$ & 0.76 & 0.54 & \\
\hline Deûle & $05 / 02 / 13$ & 6.4 & 7.97 & - & -7 & -47.6 & 670 & 3.13 & 0.44 & 1.90 & 0.19 & 5.14 & 1.50 & 5.32 & 0.015 & $4 \%$ & 0.78 & 0.55 & \\
\hline Deûle & $05 / 03 / 13$ & 8.1 & 8.3 & - & -6.90 & -47.80 & 773 & 3.44 & 0.45 & 2.02 & 0.21 & 5.87 & 1.86 & 4.80 & 0.017 & $1 \%$ & 1.23 & 1.44 & \\
\hline
\end{tabular}


Table 2: Rock composition of the geological formations sampled in the study area. The concentration of $\mathrm{Mg}$ in the Chalk samples being less than the quantification limit (ql), half the $\mathrm{ql}$ has been considered for the $\mathrm{Mg} / \mathrm{Sr}$ calculations.

\begin{tabular}{|c|c|c|c|c|c|c|c|c|}
\hline Rock sample & Rock age & $\mathrm{CaO}$ & $\mathrm{MgO}$ & $\mathrm{Sr}$ & $\mathrm{Se}$ & $\mathrm{Ca} / \mathrm{Sr}$ & $\mathrm{Mg} / \mathrm{Sr}$ & $\begin{array}{c}{ }^{87} \mathrm{Sr} /{ }^{86} \mathrm{Sr} \\
\pm 2 \delta\end{array}$ \\
\hline & & $\%$ & $\%$ & $\mathrm{mg} / \mathrm{kg}$ & $\mathrm{mg} / \mathrm{kg}$ & $\mathrm{mol} / \mathrm{mol}$ & $\mathrm{mol} / \mathrm{mol}$ & \\
\hline Silt & Quaternary & 1.1 & 1.4 & 85 & 4.1 & 202 & 358 & \\
\hline Flandres Clay & Ypresian & $<q l$ & 2.3 & 94 & 4.87 & 83 & 532 & $\begin{array}{c}0.70797 \\
\pm 0.000005 \\
\end{array}$ \\
\hline $\begin{array}{l}\text { top of the } \\
\text { Ostricourt } \\
\text { Sand } \\
\end{array}$ & Landenian & $<q l$ & 2.2 & 38 & 3.57 & 205 & 1258 & $\begin{array}{c}0.70886 \\
\pm 0.000005\end{array}$ \\
\hline $\begin{array}{l}\text { middle of the } \\
\text { Ostricourt } \\
\text { Sand }\end{array}$ & Landenian & $<q l$ & $<q l$ & 49 & 1.37 & 159 & 221 & \\
\hline $\begin{array}{c}\text { base of the } \\
\text { Ostricourt } \\
\text { Sand }\end{array}$ & Landenian & $<q l$ & $<q l$ & 52 & $<q l$ & 150 & 209 & \\
\hline $\begin{array}{c}\text { Flint Chalk, } \\
\text { total }\end{array}$ & $\begin{array}{l}\text { Turonian- } \\
\text { Senonian }\end{array}$ & 60.8 & $<q l$ & 606 & $<q l$ & 1567 & 18 & \\
\hline $\begin{array}{c}\text { White Chalk, } \\
\text { total }\end{array}$ & $\begin{array}{l}\text { Turonian- } \\
\text { Senonian }\end{array}$ & 61.8 & $<q l$ & 595 & $<q l$ & 1623 & 18 & $\begin{array}{c}0.70735 \\
\pm 0.000005 \\
\end{array}$ \\
\hline $\begin{array}{l}\text { Quantification } \\
\text { limit }\end{array}$ & & 1 & 1 & 5 & 1 & & & \\
\hline
\end{tabular}

